\title{
Historein
}

Vol $11(2011)$

Politics and History

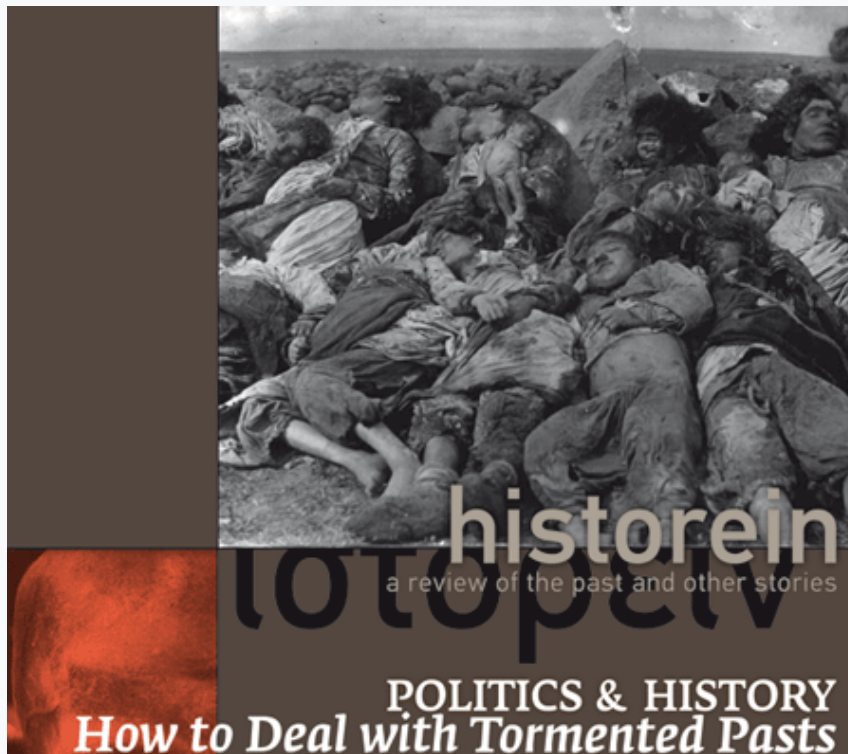

\section{Puzzles of the Past: Silences, Omissions and Unexplored Topics in History}

Thomas W. Gallant, Aris Sarafianos

doi: $\underline{10.12681 / \text { historein.145 }}$

Copyright @ 2012, Thomas W. Gallant, Aris Sarafianos

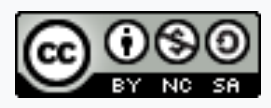

This work is licensed under a Creative Commons Attribution-NonCommercialShareAlike 4.0.

\section{Pierre Nora}

Jörn Rüsen

Wolfgang Benz

Luigi Cajani

Antoon De Baets

\section{To cite this article:}

Gallant, T. W., \& Sarafianos, A. (2012). Puzzles of the Past: Silences, Omissions and Unexplored Topics in History. Historein, 11, 136-174. https://doi.org/10.12681/historein.145 


\section{INTERVENTIONS}

\section{Puzzles of the Past: Silences, Omissions and Unexplored Topics in History}

This section presents new and original research that examines historical topics that for various reasons have not received much scholarly attention. There are in all historiographies silences, omissions and gaps. Sometimes they are purposeful, part of a collective, selective forgetting about parts of the historical record considered not worthy of being preserved as sites of memory. Other times they are caused by the belief that the source materials needed to write about a topic are not available or are inaccessible. And at still other times, they occur because the political climate in a given place at a specific time make writing about certain historical topics extremely difficult. For whatever reasons, then, gaps, lacunae and selective silences occur in the historical record. The articles to be published in this section of Historein speak to those silences, erase those lacunae and explore the hitherto uncharted topics of the past.

The first article in this series is "Women, Crime and the Courts in the lonian Islands during the Nineteenth Century" by Thomas W. Gallant. Social historians trying to write the history of nonelite women, even during the very recent past, face a formidable obstacle: the sources. Due to a lack of education and the rigours of their daily lives, nonelite women did not produce the types of documents, letters, journals or memoirs, for example, that historians often use to write social history. Where there are literary accounts about women in the past, they are mostly written by men, who thus inscribe onto women an androcentric view of their lives. Official documents are not much more help. Unfortunately, for all too many women the only traces they left in the official record were the records of their birth, marriage and death. There is one type of primary source, however, that can provide historians with insights into nonelite women's lives, and those are the records of the legal and criminal justice systems. Nonelite women, both urban and rural, encountered the legal and criminal justice systems in many and varied ways: as litigants in civil suits, as witnesses in police investigations and trials, as victims and perpetrators of crimes and misdemeanours. Consequently, there has developed a very large and rich body of historical scholarship on women, crime and the courts in early modern Europe and modern Europe and North America. But there is a glaring gap in this historiography: we know very little about the social history of women and crime in Greece, the Balkans and the Ottoman Empire. Gallant's article is a first step towards filling this gap. Using police and court records from the lonian Islands during the nineteenth century, his study gives us insights into the social world of women in one part of the Greek world. In addition, because there are a large number of studies on the topic from elsewhere in Europe during the nineteenth century, he is able to contextualise his study to show what was similar and what was different about the experience of women in the lonian Islands. He ends with a call for more research from elsewhere in the region so we can begin to write the social history of Greek women. 
John Jolly, chief of the Ionian police on the island of Zakynthos, arrived in the mountain village of Volimes late on Wednesday morning, 27 May 1863. He was confronted with a grizzly scene. The previous night someone had shot Maria Pagnopoulou through the head while she was sleeping and then set her body on fire. Jolly had received loannis Mirros'1 report that morning and, after informing the public prosecutor, he set out with a contingent of constables to investigate the crime. Some policemen started interviewing people in Volimes, while others made the short trip to Schinari, a nearby village where the deceased's family lived. Jolly and his chief detective, Ioannis Markoussas, personally interrogated Yiorgos Todassis, the deceased's husband, his brothers Dionysios and Lambrinos Todassis, and Angeliki Pagnopoulou, Maria's sister. Yiorgos had a horrible story to tell. The previous evening he and his young bride - they had been married only a few months - went to bed in the loft bedroom of their house. A gunshot woke him from his slumbers and he beheld beside him Maria, dead with her hair on fire. Bolting upright, he saw a spectre flee down the stairs. He ran out of his house screaming, and his cries aroused his brothers, who lived nearby. Others quickly joined them. Some helped extinguish the fire, while others set off in futile pursuit of the murderer. The distraught husband told Mirros that he recognised the villain, and it was none other than Angeliki. Assuming that she had fled to her father's house, Mirros dispatched some men to seize her and to bring her back to Volimes to await the arrival of the police. In a show of fraternal solidarity, Dionysios
Women, Crime

and the Courts in

\author{
the Ionian Islands
}

during the Nineteenth

Century

\section{Thomas W. Gallant}

University of California, San Diego 
and Lambrinos corroborated their brother's story, while the distraught Angeliki professed her innocence. The police, however, smelled a rat.

Their suspicions aroused, the police carefully inspected the crime scene and vigorously questioned people from the area. As Jolly related in his detailed report to the inquiring magistrate, the next day, he had Yiorgos Todassis brought before him, and he confronted the grieving husband with some questions. First, could Yiorgos explain how it was that someone could sneak through his house, climb two sets of stairs, enter his bedroom and shoot his wife, who was sleeping beside him against the wall, without waking him? Second, Jolly noted that Todassis had said that he saw his wife's hair on fire, but an inspection of the body indicated that only her legs and abdomen had been burnt and not her head. How did this happen? Third, how did he escape the flames unscathed? Fourth, was it true that his father was planning on disinheriting him because he had eloped with Maria, a girl from a poor family? Fifth, was it true that Maria was six months pregnant? And how would his father view the birth? The noose was tightening around Todassis' neck. Then, Inspector Markoussas laid a stack of papers on the table. Pointing to them, Jolly asked Todassis to explain how it was that five witnesses, whose sworn affidavits he had before him, claimed to have seen Angeliki in Schinari at the time that the murder took place. Unlike in television or the movies, the murderer did not crack and blurt out his guilt. But the jig was up. Yiorgos Todassis was arrested, tried and convicted of his wife's murder. He was sentenced to fifteen years at hard labour. ${ }^{2}$

This case reflects two realities that the Greek police knew well, and that historical research has corroborated: first, that women rarely committed murder, let alone the murder of a kinswoman, and second, that when women were killed, it was almost always by a kinsman. As we shall see, during the nineteenth century in the lonian Islands, as in much of Europe, women committed very few felonious crimes. This does not mean that women are absent from criminal justice records or that women did not interact with police and judicial authorities frequently and in important ways. They did, but, differently than men and in a very gendered way. And an examination of the history of women and crime can reveal a great deal about nineteenth-century Greek society.

In a provocative article published in the early 1990s, Malcolm Feeley and Deborah Little argued that in England over the course of the eighteenth and nineteenth centuries women largely disappeared from the criminal courts. They proposed that the reason for the "vanishing female felon" was the development of an industrial, modern society. ${ }^{3}$ The implication of their assertion, of course, is that women appeared prominently in the criminal courts in preindustrial, traditional societies. Their provocative study gave added momentum to a trend that had begun during the 1980s, and that was the historical study of women, violence and crime. To be sure, the study of women and crime among sociologists and criminologists had been going on for some time. ${ }^{4}$ But among historians, it was only when the concept of gender was an introduced as an important category of historical research that the study of women, crime and criminal justice took off. This led to the publication of a number of studies that examined the history of women and crime in Europe. ${ }^{5}$ Two points became very clear from these studies; first, that women were largely absent from the criminal records in the past and, second, that men and women were the perpetrators and victims of different types of crimes. Historians have frequently focused on 
the main categories of female crimes, such as infanticide ${ }^{6}$ and prostitution. ${ }^{7}$ The literature on those topics has continued to grow and we know a great deal about women and crime across much of Europe - with one notable exception: the Mediterranean world. Very few studies have been conducted on the history of women and crime in Spain, Italy, Greece or the Ottoman Empire, for example. ${ }^{8}$ This article, then, contributes to the existing literature by presenting a study of the engagement between women and the criminal justice system in the Mediterranean during the nineteenth century.

\section{The system}

For centuries the Ionian Islands had been part of the Venetian Empire. These "flowers of the Levant", as they were often called, provided Venice with a source of revenue. More importantly, they formed a barrier against the expansionist Muslim Ottoman Empire. During the Napoleonic wars, rule over the island passed back and forth between the Ottomans, France, Britain and Russia. However, their disposition was not clear-cut at the war's end. All of the Great Powers wanted them but none wanted any of the others to get them. After heated negotiations, it was agreed that the islands would be granted their independence as the United States of the Ionian Islands, but that they would be placed under the protection of the British crown. The result was that by 1817 the British had added the lonian Islands to their empire in the Mediterranean.

The task of crafting the institutions of imperial control in the islands fell to one man, General Sir Thomas Maitland. The situation that confronted Maitland and his fellow colonial officers was somewhat different than elsewhere in the empire. Categorically, the lonian Islands were unlike the other British colonial possessions. They were not settler colonies, dominions controlled by private companies or distant lands held by right of conquest. In addition, the culture they encountered in the islands defied easy categorisation. Ionian Greeks were white, Christian (Orthodox) and European. The British created two identities for the Greeks, one as the Irish of the Mediterranean and the other as Europe's aborigines. ${ }^{9}$ There was a sense in which the Ionian Islands were areas of the world that, by and large, were closer to Britain than other parts of the empire. I suggest that this made the task of crafting a system of colonial rule different.

In his correspondence with the British Colonial Office and with his staff, Maitland made it absolutely clear that the law was to be the linchpin of both the system of government they were establishing and the element that legitimised British rule. A legacy of bad laws and corrupt administration under the Venetians accounted for the "debased" condition of the Greeks. Maitland made it perfectly clear that he would not uphold the unjust laws of Venice. He resolved then to provide the islands with a new law code and with new institutions to adjudicate disputes and punish offenders that would be fair, impartial and which would "bring justice to the peasants' own door". Law, then, was the key to colonial rule in these islands. ${ }^{10}$

The criminal code divided offences into three categories based on their severity: delitti, offenzi and contravenzioni - essentially equivalent to felonies, misdemeanours and citable offences. The structure of the judicial system was divided into three branches: commercial, civil and criminal. 
The official languages of the courts were initially English and Italian; Greek replaced Italian in 1843. Structurally, the lowest rung of the criminal justice system was the tribunali of the judicial police. These police magistrates were always locals and they had jurisdiction over contraventions; they could render summary judgments and mete out minor punishments. They also transmitted more serious offences to the next level of the system, the criminal court. The police magistrate would bind over a defendant and the case would then be given to the advocate fiscale, who, acting in an inquisitorial role would investigate the crime, compile the evidence and then act as prosecutor at the formal hearing. Two judges heard criminal cases and they rendered the verdict. Juries played no role in the criminal justice system at any level. Above the criminal court was the Supreme Council of Justice (Supreme Consiglio di Guistiza). This body consisted of four judges, two British and two Greek, and a president, who had to be British and whom the Lord High Commissioner appointed. The supreme court's task was to hear appeals of only the most serious criminal offences. The president was also called on to cast the deciding vote in cases where the two lower court judges could not agree.

Lastly, there was the police. The police forces were a branch of the lonian civil government and so did not fall under the control of the Colonial Office; though the two often cooperated closely. The structure and organisation of the police changed over time, as various models of policing were adopted. For most of the nineteenth century the structure was as follows and was the same on each island. There was a director, or chief, of police. Under him were two or three inspectors/detectives and then a body of constables, who constituted the executive police. They patrolled the urban areas and investigated crimes. Assisting them in the countryside were rural guardsmen and village primates. Ionian Greeks, Albanians, Corsicans, Maltese and Britons staffed the police forces. These were the men who patrolled the streets, investigated crimes and forwarded cases for criminal prosecutions.

The criminal justice system in the islands generated a huge volume of documents and records, and fortunately many of these have survived and are housed in the archives in Corfu, Argostoli and London. Unfortunately, the ravages of time and earthquakes have not been so kind to the archives on Lefkada and Zakynthos, and so we have less material from them. Among historians of crime there has been an ongoing and at times fierce debate about how we measure crime. There are problems with almost every possible criminal category. "I one counts criminal indictments, for example, is that really telling us about the numbers of crimes committed or about the willingness of people to bring their disputes to the police? As I have argued elsewhere, ${ }^{12}$ most Greek men chose not to involve the authorities in solving their disputes but instead preferred to settle them on their own, usually with violence. Arrest statistics can be very valuable but do they reveal more about how the police operated or about the actual incidence of crime? Also, do we count as a crime an arrest or an indictment, even if it was an episode in which the accused was later acquitted? For that reason, some have suggested that criminal convictions provide us with the best yardstick. But do convictions really inform us about actual crimes or about how a criminal judicial system operated in a given place at a specific time? Each one of these measures has its proponents and its detractors. ${ }^{13}$ Not long ago, two excellent studies appeared that studied homicide, both quantitatively and qualitatively, using data culled from newspapers; ${ }^{14}$ they could adopt this approach because they studied two of the world's largest cities, Chicago and 
New York, respectively. Finally, there are those who argue that all crime statistics are flawed in one way or another ${ }^{15}$ and they have been joined by others who argue for a reorientation in the study of crime. They want to shift our focus away from the study of crime statistics to focus our attention instead on crime narratives. ${ }^{16}$

This study bridges both approaches. Mindful of the drawbacks with any type of crime measurement, I have created a statistical database in which I have recorded every type of crime or episodes that could be considered criminal. So, I recorded arrests, indictments and convictions, as reported in the police and court records. But I have also included data from coroners' reports, police logbooks and registers, the notes that policemen submitted after each patrol, and episodes mentioned in correspondence between judicial officials. I used a stratified random sampling strategy whereby I selected 16 years distributed over the 50 years of British rule. Using the registers kept by the office of the chiefs of police in the islands of Corfu and Kefalonia, I recorded aggregate data for 17,375 criminal indictments; five percent of these were randomly selected for detailed examination, and for the purpose of this paper, that amounted a data set of 695 cases. I recorded aggregate data on 17,075 criminal trials and once again selected a sample of five percent (683) for more detailed examination. These were augmented by an additional 220 cases, the information on which derived from other sources. Thus, my discussion of women and crime is based on a data set of 1,598 cases.

\section{Crime by the numbers}

The first general conclusion of note is that women are largely absent from the criminal justice system. Women were named either as victims or as the accused in only 266 , or sixteen percent, of 1,598 cases that I examined. In order to test the accuracy of his observation, i.e., to be sure that there was not a quirk in the dataset, I employed a few other measures. And they support the conclusion that women do not appear prominently in the records of the criminal justice system. Table 1 shows the ratio of men to women incarcerated in Corfu's prisons and jails:

Table 1. Women incarcerated in Corfu, 1836-1838, 1843

\begin{tabular}{|c|c|c|}
\hline Year ending & Men & Women \\
\hline 31 December 1836 & $261(99 \%)$ & $3(1 \%)$ \\
\hline 31 December 1837 & $254(98 \%)$ & $6(2 \%)$ \\
\hline 31 December 1838 & $274(97 \%)$ & $7(3 \%)$ \\
\hline 31 December 1843 & $323(97 \%)$ & $9(3 \%)$ \\
\hline
\end{tabular}

The very small number of women in prison might be a reflection of the courts' reluctance to imprison them. But the same picture appears if we examine another measure that might better capture the engagement of women with the police. After each shift, police officers had to hand in their notebooks in which they had recorded what had happened during their rounds and to list the persons to whom they had issued citations, tickets as it were, for minor offences such 
as public drunkenness, disorderly conduct, insubordination or disturbing the peace. In the city of Corfu in November 1858, the police issued 89 such citations, 85 (95 percent) to men and 4 (5 percent) to women. As in other nineteenth societies, then, women were largely absent from the records of the criminal justice system. I should note that I omitted from this calculation all cases involving criminal slander. As I have discussed elsewhere, slander was the crime that brought more women before the bar than any other. But it was also a crime for which tens of thousands of men were also involved. ${ }^{17}$ The inclusion of slander, then, would not alter the observation that women are largely absent from the criminal justice system and that men committed the overwhelming majority of crimes. Nonetheless it is instructive to analyse what crimes were committed against and by women. I begin with the former.

\section{Crimes against women}

Let us begin by looking at those episodes in which women were the victims of a crime. The relevant data are presented in Table 2.

Table 2. Cases where women were the victims of crime

\begin{tabular}{|c|c|c|c|c|c|}
\hline & Person & \multicolumn{3}{|c|}{ Property } \\
\hline & No. & $\%$ & No. & $\%$ & \\
\hline Male accused & 83 & 76 & 27 & 71 & \\
\hline Female accused & 36 & 24 & 11 & 29 & \\
\hline Totals & 119 & 100 & 38 & 100 & 159 \\
\hline Totals (in \%) & 76 & & 24 & & 100 \\
\hline
\end{tabular}

When a woman was the victim of violence, three-quarters of the time the assailant was a man. By almost the same percentage this was the case when she was the victim of a property crime. As suggested earlier, the numbers are important but even more significant is knowing exactly what the nature of the crimes committed against women was, i.e., what was the story behind the numbers. I begin with violent crime (Table 3).

When women were murdered, the killer was almost always a man to whom she was related. Ionian men killed twenty-nine women and in all but one, they killed a kinswoman. The causes of the disputes that led to the killings fall into two clear and distinct categories, that themselves are nicely paralleled in the incidences of male-on-male violence. A number of women were killed in the heat of the moment during an argument or a dispute. Take the case of Eleni Martino from the village of Spartia on Kefalonia. One balmy November day in 1834, she approached her husband, Andreas, who was hard at work pruning their vines. She began berating him, though the cause of her ire remains unknown. The coroner, however, recorded in gruesome detail the result of their argument. With his axe, Martinos struck his wife above her left eye with such force as to almost "lift the top of her skull off". ${ }^{18}$ On the morning of 2 September 1840, Spyros Stamatellos and his wife Angelina left their village of Kambothekera on the island of Kefalonia to work in 
their vineyard. In preparation for the imminent grape harvest, Spyros was levelling a parcel of land that would be used as the drying ground to turn the grapes into raisins. While working, he and his much younger wife - he was 55 and she was 29 - got into an argument. Unable to contain his temper, he struck her in the head with his hoe and killed her. ${ }^{19}$

Table 3. Violent crime against women by men

\begin{tabular}{|c|c|c|c|c|c|c|}
\hline & Kin & & Non-kin & & Total & \\
\hline Homicide & 18 & $\%$ & No. & $\%$ & No. & $\%$ \\
\hline $\begin{array}{c}\text { Attempted } \\
\text { homicide }\end{array}$ & 10 & 100 & 0 & 0 & 10 & 12 \\
\hline Rape & 4 & 25 & 12 & 75 & 16 & 19 \\
\hline Assault & 8 & 23 & 28 & 77 & 36 & 43 \\
\hline Battery & 1 & 50 & 1 & 50 & 2 & 2 \\
\hline Total & 41 & & 42 & & 83 & \\
\hline Total (\%) & 49 & & 51 & & & 100 \\
\hline
\end{tabular}

These murders are amply paralleled by similar slayings perpetrated by men on other men. My recent study of masculine violence found that men killed for the most trivial of reasons. ${ }^{20} \mathrm{Argu}-$ ments that arose from chance encounters and utterly banal disputes ended with someone being killed or critically wounded. There was neither premeditation nor a specific intent to kill. Take the following example, which is also one of the two cases where a non-kinsman put a woman in fear of her live. On 8 December 1853, Dimitrios Bousianos struck over the head with a stick a girl he found stealing olives from his grove. Her condition was grave and she was being treated for a life-threatening contusion. Bousianos was arrested and detained in the public jail on the charge of assault. The inquiring magistrate monitored the child's condition to determine what crime Bousianos would be charged with - assault, attempted murder or murder. Given the absence of premeditation, he was leaning toward showing leniency to the accused. ${ }^{21}$ Episodes like this one account for the majority of attacks I categorised as attempted homicides. Many women, then, died from wounds inflicted by men in the heat of the moment.

The majority of lethal attacks against women were premeditated, were committed by kinsmen, like the one with which I opened this chapter, and many were honour crimes. Every Greek man, like men in many other cultures, knew that there existed an unwritten law, which stipulated that a man who caught his wife in an adulterous affair could kill both her and her lover. Spyridon Metaxas Laskaratos from Kefalonia in his affidavit to the public prosecutor made it clear that he knew that "he had the right to act violently against the adulterous [and the adulterer] in that very moment that caught them in deed". ${ }^{22}$ As Jeffrey Adler has noted, the unwritten law "permitted and arguably encouraged a man to kill his wife's paramour or any libertine who seduced his daughter or sister". ${ }^{23}$ In the lonian Islands, women who committed adultery or premarital fornication were also supposed to die, and some did. ${ }^{24}$ 
On 3 January 1864, the body of 30-year-old Kateria Rapsomarikis was found in a well, close to the village of Katastari on Zakynthos. The police arrested her four brothers, Yiorgos, Evstathis, Arvanitakis and Dimi, and Andreas Rapsomarikis, her husband. It took the police only a few minutes to learn what everyone in the village seemed to know: Katerina had committed adultery. She had brought dishonour on her husband and her family. Because of the extended period of time that the body had been submerged, the police surgeon was unable to determine whether they had killed her and then dumped her body in the well or had been thrown in the well while still alive. ${ }^{25}$ But as hinted at in the passage from Adler, above, the focus of lethal violence was directed mainly at the libertines and less so on the women. There are a number of other examples where women were killed for honour, and they constitute approximately one-third of female murders. But to be sure, their number pale in comparison to the number of men who were men killed on account of seduction and sexual impropriety. ${ }^{26}$

In the one case in where a woman was killed by a nonkinsman, it was, at least in the view of the murderer, a crime of honour. Katerina Yianouli lived in the village of Piskopianio on Corfu and she was the object of affection of Dimos Kessinos from the nearby village of Strongilli. A match had been arranged between the two, and when she broke off the engagement, Dimos was humiliated. As he told anyone who would listen, she had dishonoured him and he would make her pay. At 11.30pm on Tuesday night, 9 March 1847, he approached her. She was standing in the doorway of her family's house talking with her brothers. At point blank range, he shot her in the head. The brothers gave chase but the killer escaped. ${ }^{27}$

Both in terms of the overall numbers of homicides committed against women and the reasons why they were killed, the situation in the lonian Islands resembles closely that which transpired in many other parts of Europe and the United States. ${ }^{28}$ The same is the true when we examine other categories of violent crime.

I recorded sixteen sexual assaults, and they accounted for 19 percent of the violent crimes against women. Every historian who has endeavoured to study rape has commented on the difficulties they encountered and the paucity of cases they found..$^{29}$ This was due partly to women being reluctant to report sexual assaults to the police and partly to the authorities being less than vigorous in prosecuting them. Of the sixteen cases that I found, only four came from crimes investigated and prosecuted by the authorities. Twelve of the rapes I recorded derived from criminal investigations of a homicide in which the deceased had been slain by a man whose kinswoman had been sexually assaulted. The man killed, of course, was the rapist, or suspected rapist. I begin, though, by examining the relationship between the victims and their assailants. In twenty-five percent of the cases, the rapist was related to the victim: once it was a cousin and in the other three it was a brother-in-law. In all of these cases, violence accompanied the rape. The case of Christina Kirigiotis is typical of this kind of attack. She was a sixteen-year-old, unmarried girl living in the village of Lakones (Kefalonia). Her sister's fiancée, Stathis Varellis, had come to her village to help with the wedding preparations. It was late in the afternoon. And while most of villagers were going for their customary walk around the village square, the accused followed Kristina, who was going to get water at a spring some ways away from the village near the chapel of Agios loannis. He approached her and asked if he could help her carry the water 
buckets back to the house. She refused and told him to go away because she was ashamed at being at being seen on her own with a man. He knocked her to the ground and raped her. She screamed. Konstantinos Giris Stamatello heard her cries and came running. Stathis took off. The cry went up in the village. Ilias Vrigavis and two others caught him and brought him back to the village. Kristina's father and brothers, with knives drawn and blood burning, tried to get at him but were restrained by the district constable, Vassilis Phanos, who happened to be making his rounds at the precise moment of the crime. The constable immediately sent for a detachment from the British garrison at Agios Yiorgos to come and escort Stathis to Argostoli because he feared that the victim's kinsmen would kill the rapist and maybe even himself if help did not arrive soon. ${ }^{30}$ The constable was right to be worried.

When women were sexually assaulted by men to whom they were not related, the stories are different. In some of the cases, we are dealing with a consensual union. In a couple of them, for example, what happened was that the master of a great house filed rape charges against one of his male servants or field workers who had taken up with one of his domestic servants. In both cases, in fact, the women had already run off with the men. ${ }^{31}$ In the other cases, the victims were women who were especially vulnerable, like the widow Elena Coeno.

Coeno had moved to Corfu from Malta with her husband Martin. There they established a dry goods store, which she continued to operate after her husband's death. At 2.30pm in the afternoon on 19 December 1843, Periklis Monopolis entered her store to buy some dry goods - beans and the like. She went into a back room to get some salt from a sack. He followed her and raped her on the floor. He claimed that she was a prostitute and that he went there not to buy food but to "do man's business". People from the neighbourhood gave evidence, the gist of which was that Coeno was an "honourable woman" and that Monopolis was a "disreputable character". The presiding magistrate of the tribunal of the judicial police, Antonio Zen, bound Monopolis over for trial in the criminal court. ${ }^{32}$

Her case, as I noted earlier, was one of the few that made it into the courts. Most sexual assaults were never reported to the police and knowledge about them comes only through the investigations of homicide cases, like the following. While pasturing her family's cattle in a field, Katerina Vlassis was assaulted by Nikolaos Sabatis. When she returned to her village without her "girdle", her brother armed himself with two pistols and a knife and swore not to return until blood had been spilt. He was home in time for dinner and Sabatis' body was found in a field with a bullet in his heart. ${ }^{33}$ The sexual assault against Katerina Vlassis was never reported to the authorities, and we only have a record of it because of her brother's action. Rape, like seduction, mandated that a man was owed blood and so ideally he should slay the person who assaulted his kinswoman, and in studying such murders we can learn about sexual assaults against women. An examination of assaults and batteries committed against women shows that this type of violence differed sharply from murder or sexual assault. First, there were more of them: 43 percent of violence against women were assaults, and second, 77 percent of the time the assailant was not a relative. Here are some typical examples. The prostitute Tasoula Baltzos swore out an arrest warrant against two soldiers from the British Royal Artillery regiment for having assaulted her. The police physician's report indicated that she had been severely beaten. She could 
identify the men but did not know their names. ${ }^{34}$ While on patrol in the Plaka district in Argsotoli on 18 April 1859, Constable Andreas Panagouplos heard a row in the wine shop owned by Andreas Bachio. A British soldier had assaulted Penelopi Bilirakis; he had punched her in the face. The constable detained the soldier while the barman went to the police station and informed the desk sergeant. Soon thereafter two military police arrived from the British garrison and took the soldier into custody. ${ }^{35}$ In like vein, Constable Andreas Zepatos responded to cries of distress from the wineshop run by Panagis Gerondini. When he entered he found Nina Makris bleeding profusely from a cut on her face inflicted by Tomaseo Lazarinas. He arrested him and the case was forwarded to the police magistrate. ${ }^{36}$ Dionysia Chikirais from Mandouka on Corfu assaulted Konstantina Konderas by hitting her in the head with her shoe after they had become embroiled in an argument while drunk. ${ }^{37}$

Cases of assault, then, fit into a very clear pattern. Women, usually working women, were beaten sometimes by men and sometimes by other woman, and almost invariably, the attack occurred in a public place where alcohol was being consumed. Completely absent from the criminal justice records are cases of wife-beating. Unless Greece was completely different from many other places in Europe ${ }^{38}$ domestic assaults probably occurred but I have found neither records nor mention of them.

\section{Crimes committed by women}

Turning now to an examination of crimes committed by women, the first point of importance to note is that there were relatively few of them. In the database I compiled, women committed only seven percent of the total number of recorded crimes. Table 4 shows the distribution of those cases.

Table 4. Criminal indictments or citations issued against women

\begin{tabular}{|c|c|c|c|c|c|c|c|c|c|c|}
\hline & Person & & Property & & Adultery & & $\begin{array}{l}\text { Public } \\
\text { order }\end{array}$ & & Total & \\
\hline & No. & $\%$ & No. & $\%$ & No. & $\%$ & No & $\%$ & No. & $\%$ \\
\hline Female & 19 & 52 & 5 & 45 & 0 & 0 & 0 & 0 & 24 & 22 \\
\hline Male & 7 & 19 & 6 & 55 & 10 & 100 & 0 & 0 & 23 & 21 \\
\hline Infant & 10 & 27 & 0 & 0 & 0 & 0 & 0 & 0 & 10 & 9 \\
\hline State & 0 & 0 & 0 & 0 & 0 & 0 & 52 & 100 & 52 & 48 \\
\hline Total & 36 & & 11 & & 10 & & 52 & & 109 & \\
\hline $\begin{array}{l}\% \text { of } \\
\text { total }\end{array}$ & 34 & & 10 & & 9 & & 47 & & & \\
\hline
\end{tabular}

Almost half of the crimes committed by women were contraventions of public order statutes for which the police gave them citations. The second largest category was violent crimes against other people, and I begin with the most serious of these: murder. 
When women killed, it was always with premeditation and it was invariably against family members. I begin with two cases that exemplify noninfanticide murders. The village of Beloussis on Corfu was all a buzz on the night of 18 September 1861. The body of nine-year-old Angelina Kresia had been found in a small, exposed well located a considerable distance from the village. The primate sent a boy to the rural guard's station to report the discovery of the body. A magistrate and the police physician were sent to examine the body. The doctor found traces of violence. After asking questions in the village, the magistrate started to have suspicions about the girl's 21 -year-old stepmother, Katerini Tourbanou. She had told her husband when he returned from town that she had sent the girl to her grandmother's house. Many villagers told the investigators that Tourbanou had never liked the stepdaughter and that she resented her presence in the house. The magistrate decided that Tourbanou had motive, means and opportunity and so he ordered her arrest. The case was forwarded to the public prosecutor with a request that he proceed to a trial in the criminal court. ${ }^{39}$

At $11 \mathrm{pm}$, on 19 March 1839, the body of Margariti Perdikomattis was found behind a wall in the fields near the village of Kouramades on Corfu. According to the police physician's report, Perdikomattis had been brutally slain, sustaining at least 16 stab wounds - six in the head, five in the ribs, one on the left hand and one in the throat; he concluded further that four of the wounds could have been the cause of death. Police inspector Antonios Zervos led the investigation of the murder. He learned that the body had been found after the village primate had ordered a search. He said that he did so because the deceased man's wife, Maria Perdikomatti, had reported to him that her husband was missing. The police thought that something was amiss because Maria manifested a remarkable sangfroid demeanour when they questioned her, leading them to conclude that "her manner and behaviour ... looked very suspicious". Village gossip disclosed a rumour that she was having an affair with Yiorgios Chytiris from the village of Trileno. Taking this information seriously, the police raided and searched the house of Chytiris' mother, with whom he lived. And they found hidden in a pile of logs a pair of men's breaches, covered in blood. Concluding that the circumstantial evidence was sufficient to sustain a charge of murder against Chytiris, they arrested him, and deducing that the wounds could only have been inflicted by two assailants, they arrested Maria. The pair was convicted of murder; he was executed and she was sentenced to four years in prison. The criminal court judges explained that the discrepancy in the sentences was due to the fact that, while they were sure that Maria was involved in the killing, they could not determine what exactly she did. So they gave her as severe a sentence as they thought warranted by the evidence..$^{40}$

The most common type of murder woman committed was infanticide. So much so that whenever the body of an infant was discovered, the police immediately suspected the mother. But, as was often the case with infanticides, the police faced real difficulties in investigating the deaths of babies, beginning with determining the cause of death. The typical narrative reads like this: a body was found, usually in the fields near a settlement, and the village headman would report the finding to the police, who would begin an investigation. The body would be sent to the police physician for examination. ${ }^{41}$ The police would start interviewing villagers about their women trolling for gossip, as it were. If the coroner reported that the baby had been killed by human action, then almost invariably the mother was arrested. 
On the evening of 2 June 1859, a dead infant was found outside of the church in the village of Gaitani (Zakynthos). The baby's mother, Zoja Pastra, was arrested and charged with infanticide. Her case went before the criminal tribunal. She maintained her innocence. And, absent a confession, the prosecution had a very hard time making the case. There were no witnesses to the death. The medical evidence was inclusive: the baby may have been stillborn, as the mother maintained. Plus, her explanation that she had left the body at the church so that it would be closer to God and that she did not report the death to the authorities out of fear sounded plausible. She was acquitted. ${ }^{42}$ In many cases, however, woman who killed their babies broke down and confessed. Paraskevi Havouri, the wife of Spyridon, admitted to strangling her baby boy out of a wish "to hide her dishonour". The baby was not her husband's child. She had been married for only five months. Instead the child belonged to loannis Kounepianos, a peasant from an adjacent village. One wonders, however, if she would have confessed if Stamatis Rodittis, a peasant from her same village, had not told the police that he had helped her bury the child. She had told him that the baby had been stillborn. She was convicted of murdering her baby and sentenced to five months in prison. ${ }^{43}$

I found only one case of infanticide that deviated from this stock narrative. And that was the case of Katernia Livathinos from the city of Zakynthos. She was married to a ship captain named Dionysos Livathinos. He had been away at sea for three years. He returned to the island five months before, stayed for a few days and then went off to sea again.44 "During the interval [between his visits home] his wife was delivered of a child born in its ninth month, which he said was not his own, as he had only been five months in Zakynthos - the woman, however, said that she had miscarried in her fifth month, and thus buried the child. I transmitted the affair to the inquiring magistrate, and it results from medical faith, that the child was born in its ninth month, but it could not be proved if it was born alive, or dead, as it was found in a putrefied state". ${ }^{45}$ Lacking clear evidence that the baby was maliciously killed rather than being born dead, the case was dismissed. There is no record as to what Captain Livathinos did when he learned the news.

One option that he could have chosen was to charge his wife with adultery, an offence under the Ionian criminal code. Adultery constituted nineteen percent of the crimes committed by women. But, and it is a very important qualification, I learned of the majority of them not from arrest records or from criminal indictments for adultery but from investigations of homicides. In fact, in only one-quarter of the episodes where a woman's adultery was discovered was she charged with a crime, and all of them fit the same pattern. In all the instances where a man swore out a criminal complaint against his wife for adultery, he was from the middle class. Take the case of Dr Nikolaos Rasin, for example. He was a member of the Kefalonian gentry and was married to a much younger woman named Konstantina. When he discovered that she was having an affair with a police constable, Dimitrios Menegatos, he swore out criminal complaints against both of them on the charge of adultery. Mengatos was dismissed from the lonian police force; what happened to her is unknown. ${ }^{46}$ Spyridon Metaxas Laskaratos, when he discovered his wife's adultery, instead of invoking the unwritten law as discussed earlier, charged her with adultery. ${ }^{47}$

Most men, however, held the unwritten law near and dear to their hearts. One of the most common causes of revenge killing was sexually inappropriate behaviour by women, in particular a 
wife's adultery or a daughter's sexual indiscretion. Panayiotis Plarinos had been conducting an illicit affair with his cousin's wife. Few were surprised, therefore, when on the night of 15 June 1859 the cuckolded husband and his wife's brother gunned him down. ${ }^{48}$ The involvement of men from both families made the act even socially more appropriate because her actions had brought shame to both families. In other words, affinal kinsmen often cooperated in taking action to cleanse with blood a stain on their honour. We learn, then, about the majority of adulteries not because someone was charged with that crime but from homicide cases in which one of the adulterers, usually the man, had been slain. So while adultery was not too uncommon, prosecuting women for it was.

Women rarely committed crimes against property (10 percent), and almost all of these offences were petty thefts committed by domestic servants. The following case is typical. Ioannis Anninos Stavrou filed charges against his domestic servant, Elia de Saterno, for theft. He accused her of stealing some of his wife's jewellery from his house. ${ }^{49}$ The only case that differs significantly from the rest involved a woman who might be considered a nineteenth-century con artist. Mrs Theresa Makris ran the following scam in Corfu. She would petition for public assistance because she was indigent. "Friends" in the government would give her monies, totalling $\$ 1,239$. She would then lend the money out on bottomry loans. Eventually the misappropriation of funds was discovered and the conspiracy revealed. She was sentenced to three days in jail and ordered to repay the money she stole, plus court costs..$^{50}$

The activity that more than any other brought women into contact with the police was prostitution. Their crime was not prostitution per se, as that was legal but regulated. The regulations in the lonian Islands, for example, mandated that all prostitutes had to register with the police the day they arrived in a municipality and inform them if they intended to move. At the beginning of each year, they had to report to the police to verify their registration. The women's activities and physical conditions were carefully monitored. Women could only work out of a residence, usually a hotel or a wine shop, in one of the neighbourhoods approved of by the police. Once a month all prostitutes had to undergo a physical examination by a physician appointed by the chief of police and to undergo mandatory treatment if they were suffering from a venereal disease. ${ }^{51}$ Because the women had to register with the police and had to undergo periodic examinations by medical officials, records were kept about them, and these provide us with our best sources for studying prostitution. And when women who were prostitutes or who worked in ancillary occupations fell afoul of the law, it was usually for activities carried out in the places and in the social milieu where prostitution flourished. ${ }^{52}$

Forty-eight percent of criminal indictments or criminal citations issued against women were for offences against public order, and almost all of them involved women behaving badly in public places such as brothels or bars. On 25 November 1858, Loli Anantho was cited for solicitation in a restricted area. She was soliciting clients in front of Corfu's public theatre. ${ }^{53}$ Zambi Limbrakia, Floria Alambourou and Maria Gramilina were just a few of the women who received citations for public insubordination, a catch-all category used to punish people who failed to obey the police or who insulted officers who were on duty. At $1 \mathrm{pm}$ on the Via Pozretto in Corfu, Maria Condon, wife of Guglielmo Condon, was found sitting on the ground with her two children, 
aged one and six years old. Maria was quite drunk. The officers helped her to her feet and told her to return to her apartment. She resisted and cursed them. After she had calmed down, she promised to take the children home. The officers gave her a citation and warned her to keep the peace. But shortly thereafter the officers found her and the children at the Spianada. In their reports, the constables noted that both she and the children were in very poor health. They also emphasised that she was a public nuisance, whom the police had found being disruptive in public on numerous occasions. ${ }^{54}$ Women who made a nuisance of themselves too frequently were subjected to special treatment by the police. Since their crimes were not delicts or offences but only contraventions, they were not punishable by incarceration. And so the police adopted other measures to deal with them. Stamatella Giolana ${ }^{55}$ and Anastassia Valsamachi, ${ }^{56}$ for example, were two such women and they were locked up in the lunatic asylum until the police determined that they had calmed down. ${ }^{57}$

So far women appear to be largely passive in their dealings with the police. They were acted upon rather than being actors in their own right. I want to examine one final area where women interacted with the criminal justice system and that was the practice of women appealing to the police and judicial authorities to act on their behalf. The following examples capture the essence of women's petitions. In some case, they appealed to the authorities to protect them, to act in loco virens or as their husband or father should. On 8 July 1820, Katerina Strongilliou, a resident of Corfu town, wrote to Captain Michael Krumm, the chief of police. She solicited his help. She was an "indigiente" woman and her landlord was threatening to throw her out into the street. She was a widow and had no one to protect her. Would he please help her and make the landlord leave her in peace $?^{58}$ Angela Venier had Antonis Romanos write a letter on her behalf to Spyros Sarlis, deputy chief of police on Zakynthos, requesting his help. Her husband had abandoned her and migrated abroad. Now his creditors were seeking payment from her. Manolis Kassarachis, in particular, had been harassing her, demanding that she pay him the 100 jars of olive oil that her husband owed him. She complained that Kassarchis had made her life miserable and she demanded that Sarlis and the police make him stop. ${ }^{59}$

On other occasions, women launched appeals on behalf of others, usually kinsmen. Anna, the wife of Gerasimos Kondoyiannis, for example, appealed to the supreme court to have her husband, who was in jail for debt, transferred to their village so that he could oversee the disposal of property which would provide them with the funds to pay off their debts. ${ }^{60}$ Ilia Manolato appealed to the supreme court for mercy for her son, Panayiotis. She was poor and had only him to support her. So she pleaded to the justices please to release him so that he could support her. ${ }^{61}$

These petitions and the hundreds like them show us women taking their grievances to the highest levels of the criminal justice system - the chiefs of police and the supreme court - to intervene on their behalf to right a wrong or to assist a loved one. In other words, they endeavoured to deploy a system that usually excluded them to work on their behalf. Unfortunately, the sources do not often allow us to know how the system responded. But occasionally it did favourably. Pencilled in the margin of Ilia Manolato's letter was a recommendation by the chief clerk of the supreme court that the young man in question be released and transported from the prison on Zakynthos to one on Corfu because he was of good character and was in jail for a minor offence. 
Hopefully he took care of his mother.

This study of gender and the criminal justice system in the lonian Islands during the nineteenth century, which is still in its early stages, by and large buttresses the current orthodox view regarding women and the criminal justice system in Europe. Women in traditional, patriarchal rural societies, for the most part, had little engagement with the police and the courts. Outside of a narrow range of "female offences", women seldom came before the bar as criminal offenders. In a society dominated by a cultural ethos that prized masculine aggression and in which honour and the vendetta defined manliness, when women were the victims of violence, it was male kinsmen and not the courts and the police that meted out justice and retribution. And so while the aggregate picture I have sketched out in this paper largely supports our current understanding, there are four areas where the situation in the Ionian Islands differs from elsewhere in Europe.

1 The female homicide rate is higher than other places; in other words proportionally more women were murdered in the lonian Islands than in other regions of Europe.

2 The number of reported cases of sexual assault is exceedingly low compared to elsewhere.

3 The assault and battery rates, especially the reported rate of domestic violence, are substantially lower.

4 The rate for property crimes committed by women is lower as well.

The explanation for the first two points, I suspect, is rooted in the male-dominated ethos of selfhelp. As I have discussed in a recent piece on masculine violence, for much of the nineteenth century lonian men chose to handle disputes in a very aggressive, often violent manner and on their own rather than turning to the authorities. This behaviour began to change from mid-century onwards but the older pattern of behaviour persisted until well into the twentieth century. As we have seen, men killed women for a variety of reasons but the vast majority of them were in confrontations that touched on masculine identity. The low number of reported sexual assaults can be accounted for similarly; men chose to deal with rapists personally and violently rather than involving the courts and the police. The "rules" of masculinity mandated it. And so very few sexual assaults were reported; though, as we have seen, there were many murders where the police knew or strongly suspected that a man had been slain because he had sexually assaulted someone. The paucity of reports of repeated, nonlethal domestic violence is more difficult to explain. I suggest tentatively that men might not have routinely beat their wives out of fear that doing so might incur the wrath of her kinsmen. Another, and not mutually exclusive, explanation is that, once again, people opted to deal with domestic issues privately rather than involving public authorities, and thereby airing the family's dirty laundry. Lastly, regarding the very low rate of crimes against property committed by women, I suspect that it is part of a broader cultural pattern in that overall the rate of property crimes is lower in the lonian Islands than in the rest of Europe. But accounting for that cultural pattern requires much more research and more studies from elsewhere in Greece. 
This brings me to my last point. We have very few histories of crime and criminal justice in Greece or the Ottoman Empire and so, while it is possible to place the case of the lonian Islands in a broader western European context, we cannot yet do so for a Balkan or southeastern European or even eastern Mediterranean context. To what extent and in what ways - if at all - does the story in the lonian Islands differ from elsewhere in Greece or in Greek communities in the Ottoman Empire? In a more multicultural context, like the Ottoman Empire, do the patterns of criminal behaviour, both male and female, differ between the various ethnic and religious groups? Only when we have more detailed social historical studies of gender and crime empirically grounded in this part of the world can we identify similarities and differences in the ways that men and women dealt with the disputes that arose in their daily lives and the role that law and criminal justice played in dealing with them. Ironically, then, while we can place case studies, like this one, into a broader European context, we cannot situate it into a narrower Greek context. And that needs to change.

\section{NOTES}

1 Mirros was the primate or headman of the village and as such it was his duty to report to the police any illegal activities in his jurisdiction.

2 The documents used in this study come from three archives: the British National Archives, and documents from it are cited as The National Archives (TNA): Public Record Office (PRO) Colonial Office (CO) 136; the General State Archives (GAK) Corfu; and the General State Archives (GAK) Kefalonia. Here, TNA: PRO CO 136/952/1, encls 22-25; 136/954/2, encl. 8.

3 Malcolm Feeley and Deborah L. Little, "The Vanishing Female Felon: The Decline of Women in the Criminal Process, 1687-1912", Law and Society Review 25/4 (1991): 719-757.

4 See Frida Adler, Sisters in Crime: The Rise of the New Female Criminal, New York: McGraw-Hill, 1975. Dorie Klein, "The Etiology of Female Crime: A Review of the Literature", Issues in Criminology 8 (1973): 3-30; Dorie Klein and June Kress, "Any Woman's Blues: A Critical Overview of Women, Crime and the Criminal Justice System”, Crime and Social Justice 5 (1976): 34-49; Rita J. Simon, Women and Crime, Lexington, MA.: D.C. Heath, 1975.

5 See, for example, the pioneering works of Anna Clark, Women's Silence, Men's Violence: Sexual Assault in England, 1770-1845, New York: Pandora, 1987; Lucia Zedner, Women, Crime and Custody in Victorian England, New York: Oxford UP, 1991; Caroline Conley, The Unwritten Law: Criminal Justice in Victorian Kent, Oxford: Oxford UP, 1991, Maria Tatar, Lustmord: Sexual Murder in Weimar Germany, Princeton, N.J.: Princeton UP, 1995 and more recently studies such as those by Garthine Walker, Crime, Gender and the Social Order in Early Modern England, New York: Cambridge UP, 2003; Jennine Hurl-Eamon, Gender and Petty Violence in London, 1680-1720, Columbus: Ohio State UP, 2005; Deirdre Palk, Gender, Crime and Judicial Discretion, 1780-1830, Woodbridge: Boydell Press/Royal Historical Society, 2006, - to name but a few.

6 James M. Donovan, "Infanticide and the Juries in France, 1825-1913", Journal of Family History 16/2 (1991): 157-176; Ann R. Higginbotham, "'Sin of the Age': Infanticide and Illegitimacy in Victorian London", Victorian Studies 32/3 (1989): 319-337; Robert W. Malcolmson, "Infanticide in the Eighteenth Century", in J.S. Cockburn (ed.), Crime in England, 1550-1800, London: Heineman, 1977, 187-209; Lionel 
Rose, Massacre of the Innocents: Infanticide in Great Britain, 1800-1939, London: Routledge, 1986; Regina, Schulte, "Infanticide in Bavaria in the Nineteenth Century", in Hans Medick and David Warren Sabean (eds), Interest and Emotion: Essays on the Study of Family and Kinship, New York: Cambridge UP, 1986, 77-102; Otto Ulbricht, "Infanticide in Eighteenth Century Germany", in Richard J. Evans (ed.), The German Underworld: Deviants and Outcasts in German History, New York: Routledge, 1988, 108-140; Stephen Wilson, "Infanticide, Child Abandonment, and Female Honor in Nineteenth-Century Corsica", Comparative Studies in Society and History 30 (1988): 762-783.

7 Lynn Abrams, "Whores, Whore-Chasers, and Swine: The Regulation of Sexuality and the Restoration of Order in the Nineteenth Century German Divorce Court", Journal of Family History 21/3 (1996): 267280; Alain Corbin, Women for Hire: Prostitution and Sexuality in France after 1850, Cambridge: Harvard UP, 1990; Barbara A. Engel, "St. Petersburg Prostitutes in the Late Nineteenth Century: a Personal and Social Profile", The Russian Review 48/1 (1989): 21-44 (24); Laura Engelstein, "Gender and the Juridical Subject: Prostitution and Rape in Nineteenth-century Russian Criminal Codes", The Journal of Modern History 60/3 (1988): 458-495; Mary Gibson, Prostitution and the State in Italy, 1860-1915, New Brunswick: Rutgers UP, 1986, and Judith R. Walkowitz, Prostitution in Victorian Society: Women, Class and the State, Cambridge: Cambridge UP, 1980.

8 There are, of course, a small number of works on certain aspects on female criminality: Mary Gibson's

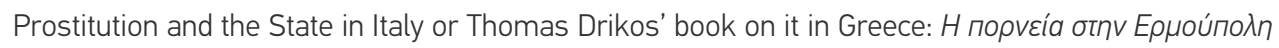
to 190 a ávva [Prostitution in Ermoupoli in the nineteenth century], Athens: Elliniki Grammata, 2002. Efi Avdela has published an excellent study of homicide in Greece, including crimes against women (“ $\Delta \iota$ á

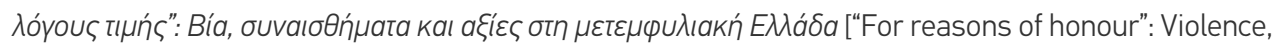
emotions and values in post-civil-war Greece], Athens: Nefeli, 2002) but her study concentrates on the 1950 s and 1960s. What stands out is that works like theirs are among the very few publications.

9 Thomas W. Gallant, Experiencing Dominion: Culture, Identity and Power in the British Mediterranean, Notre Dame: University of Notre Dame Press, 2002, 15-55.

10 For an extended discussion of the criminal justice system that the British Colonial Office established on the islands, see Thomas W. Gallant, “'When Men of Honor' Met 'Men of Law': Violence, the Unwritten Law and Modern Justice", in Efi Avdela, Shani d'Cruze and Judith Rowbotham (eds), Crime, Violence and the Modern State, 1780-2000, London: Edwin Mellen, 2010, 69-92.

11 Bruno Aubusson de Cavarlay, "Can Criminal Statistics Still be of Scientific Use? The French Criminal Justice System, 1831-1981", Historical Methods 26/2 (1993): 69-84; A. Keith Bottomley and Clive A. Coleman, "Criminal Statistics: The Police Role in the Discovery and Detection of Crime", International Journal of Criminology and Penology 4 (1976): 33-58. Peter C. Hoffer, "Counting Crime in Premodern England and America: A Review Essay", Historical Methods 14/4 (1981): 187-193: Neal Alone, "Evaluating Court Statistics as a Data Source for Studying Nineteenth Century Crime", Historical Methods 26/2 (1993), 85-93; Howard Taylor, "The Politics of the Rising Crime Statistics of England and Wales, 1914-1960", Crime, History \& Societies 2/1 (1998): 5-28; Howard Taylor, "Rationing Crime: The Political Economy of Criminal Statistics since the 1850s", Economic History Review 51/3 (1998): 569-590.

12 Thomas W. Gallant, "Honor, Masculinity, and Ritual Knife-fighting in Nineteenth Century Greece", American Historical Review 105/2 (2000): 359-382, and Gallant, “'When Men of Honor'”.

13 Cockburn, Crime in England; Ted R. Gurr, "Crime Trends in Modern Democracies Since 1947", International Annals of Criminology 16 (1977): 41-85; Idem, "Historical Trends in Violent Crime: A Critical 


\section{Interventions}

Review of the Evidence", Crime and Justice: An Annual Review of Research 3 (1981): 295-353; Idem, "Historical Trends in Violent Crime: Europe and the United States", in Violence in America: Volume 1; The History of Crime, Newbury Park: Sage, 1989; Roger Lane, "Crime and the Industrial Revolution: British and American Views", Journal of Social History 7 (1974): 287-303; Lawrence Stone, "Interpersonal Violence in English Society, 1300-1980", Past \& Present 101 (1983): 22-33; Robert D. Storch, "Policing Rural Southern Before the Police: Opinion and Practice, 1830-1856", in Douglas Hay and Francis D Snyder (eds), Policing and Prosecution in Britain, 1750-1850, Oxford: Clarendon, 1989; Howard Zehr. "The Modernization of Crime in Germany and France, 1830-1913", Journal of Social History 8 (1974): $117-141$.

14 Jeffrey S. Adler, First in Violence, Deepest in Dirt: Homicide in Chicago, 1875-1920, Cambridge, MA.: Harvard UP, 2006; Eric H. Monkkonen, Murder in New York City, Berkeley: University of California Press, 2000.

15 Manuel Eisner, "Modernization, Self-Control and Lethal Violence: The Long-term Dynamics of European Homicide Rates in Theoretical Perspective", The British Journal of Criminology 41 (2001): 618-638 and Idem, "Long-term Historical Trends in Violent Crime", Crime and Justice 30 (2003): 83-142.

16 Stuart Carroll, "Introduction", in idem (ed.), Cultures of Violence: Interpersonal Violence in Historical Perspective, New York: Palgrave Macmillan, 2007, 1-46, and idem (ed.), Cultures of Violence: Interpersonal Violence in Historical Perspective, Basingstoke: Palgrave Macmillan, 2007. Amy Gilman Srebnick and René Lévy, Crime and Culture: an Historical Perspective, Burlington, VT: Ashgate, 2005; and J. Carter Wood, Violence and Crime in Nineteenth-century England: The Shadow of Our Refinement, New York: Routledge, 2004, and idem, “Conceptualizing Cultures of Violence and Cultural Change", in Stuart Carroll (ed.), Cultures of Violence: Interpersonal Violence in Historical Perspective, New York: Palgrave Macmillan, 2007, 79-98.

17 Gallant, Experiencing Dominion, 155-8.

18 TNA: PRO CO 136/121/5, encl. 18.

19 GAK Kefalonia 121: bound correspondence, 1840-1845, encl. 17.

20 Gallant, “'When Men of Honor'", 8-9.

21 TNA: PRO CO 136/817/1, encl. 18.

22 TNA: PRO CO 136/1306, encl. 2. The twist in this case is that he did not exercise his right. Instead of choosing the unwritten law, he filed for divorce from his wife and swore out a criminal complaint against the lover for adultery.

23 Adler, First in Violence, 108-9. He also noted that many US states had laws that recognised such killings as justifiable homicides, and in one case, that of Texas, the law was not changed until 1973 (314, note 78). See also Conley, The Unwritten Law.

24 For a crosscultural, comparative study of female homicides in the name of honour, see Nancy. V. Baker, Peter R. Gregware and Margery A. Cassidy, "Family Killing Fields: Honor Rationales in the Murder of Women", Violence Against Women 5/2 (1999): 164-184.

25 TNA: PRO CO 136/979.

26 Gallant, “'When Men of Honor'”, 79-80.

27 TNA: PRO CO 136/748/5, encl. 32. 
28 Adler, First in Violence, 45-20; Clark, Women's Silence; Conley, The Unwritten Law; D'Cruze 1998; Robert M. Ireland, "The Libertine Must Die: Sexual Dishonor and the Unwritten Law in the Nineteenthcentury United States", Journal of Social History 23/1 (1989): 27-45; Joachim Kersten, "Culture, Masculinities and Violence against Women", British Journal of Criminology 36/3 (1996): 381-395; Eric A. Johnson, "Women as Victims and Criminals: Female Homicide and Criminality in Imperial Germany, 1873-1914", Criminal Justice History 6 (1985): 151-175; Kenneth Polk, “Masculinity, Honour, and Confrontational Homicide", in Kathleen Daly and Lisa Maher (eds), Criminology at the Crossroads: Feminist Readings in Crime and Justice, New York: Oxford UP, 1998, 188-205; Zedner, Women, Crime and Custody; Elicka S.L. Peterson, "Murder as Self-Help: Women and Intimate Partner Homicide”, Homicide Studies 3/1 (1999): 30-46.

29 Clark, Women's Silence; Conley, The Unwritten Law; Shani D'Cruze, Crimes of Outrage: Sex, Violence and Victorian Working Women, London: UCL Press, 1998; Karen Dubinsky, Improper Advances: Rape and Heterosexual Conflict in Ontario, 1880-1929, Chicago: University of Chicago Press, 1993; Engelstein, "Gender"; Manon van der Heijden, "Women as Victims of Sexual and Domestic Violence in Seventeenth-century Holland: Criminal Cases of Rape, Incest, and Maltreatment in Rotterdam and Delft", Journal of Social History 33/3 (2000): 623-644; Zedner, Women, Crime and Custody.

30 GAK Kefalonia 121: police correspondence, 1836, dispatches 19-21.

31 TNA: PRO CO 136/345, encl. 18, 12 Aug 1845; GAK Corfu EA 61, indictment no. 18, 12 Oct 1858.

32 GAK Corfu EA 301, indictment no. 34.

33 TNA: PRO CO 136/683/15, 27 Sept 1837.

34 TNA: PRO CO 136/868/15, encl. 86., 12 Aug 1859.

35 GAK Kefalonia, sergeant's logbook, 1859.

36 GAK Kefalonia, police correspondence, 1832-1833.

37 GAK Corfu EA 121, case 11, 8 Nov 1834.

38 Ann-Louise Shapiro, Breaking the Codes: Female Criminality in Fin-de-Siècle Paris, Stanford: Stanford UP, 1996; Maeve E. Doggett, Marriage, Wife-beating, and the Law in Victorian England, Columbia, SC: University of South Carolina Press, 1993; Anna Clark, "Domesticity and the Problem of Wifebeating in Nineteenth-century Britain: Working-class Culture, Law and Politics”, in Shani D'Cruze (ed.), Everyday Violence in Britain, 1850-1950: Gender and Class, New York: Longman, 2000, 27-40; John E. Archer, “'Men Behaving Badly'?: Masculinity and the Use of Violence, 1850-1900”, in D'Cruze (ed.), Everyday Violence, 41-54.

39 GAK Corfu EA 468/172.

40 TNA: PRO CO 136/672, encl. 21.

41 TNA: PRO CO 136/1292, 27 May 1847.

42 TNA: PRO CO 136/877, no. 9580, 24 Jun 1859.

43 TNA: PRO CO 136/870, no. 9580, 10 Aug 1859. Paraskevi Havouri did have another option. She could have surrendered her baby to the island's foundling hospital, see Thomas W. Gallant, "Agency, Structure and Explanation in Social History: The Case of the Foundling Home on Kephallenia, Greece, during the 1830s", Social Science History 15/4 (1991): 479-508. 


\section{Interventions}

44 This was very common. Numerous lonian islanders worked abroad for extended periods of time and returned home infrequently. They nonetheless married local woman and maintained a home in their natal community. On this practice, see Thomas W. Gallant, "Tales from the Dark Side: Transnational Migration, the Underworld and the 'Other' Greeks of the Diaspora”, in Dimitris Tziovas (ed.), Diaspora and Migration: Otherness, Identity and Movement In and Out of Greece, London: Ashgate, 2009, 17-31.

45 GAK Corfu EA 468/163, report by police chief Edward Barr, 10 Sept 1861.

46 GAK Corfu 1829, 31 Jul 1848.

47 TNA: PRO CO 136/1306, encl. 2.

48 TNA: PRO CO 136/868/15, 17 Jun 1859.

49 TNA: PRO CO 136/1292, 25 May 1847.

50 TNA: PRO CO 136/1270, 5 Feb 1817.

51 Gallant, Experiencing Dominion, 65-66; idem, “Tales from the Dark Side", 12-14; see also Drikos, H

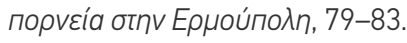

52 For a more detailed discussion of prostitution on Corfu, see Gallant, "Tales from the Dark Side."

53 GAK Corfu EA 1594.

54 TNA: PRO CO 136/727/15, encl. 77, 24 Oct 1845.

55 TNA: PRO CO 136/672, encl. 68, 29 Aug 1839.

56 TNA: PRO CO 136/1292, encl. 12, 26 Jan 1847.

57 Throughout the nineteenth century, the police and the judiciary wrestled with the problem of how and where to incarcerate women. I address this issue in another article.

58 GAK Corfu 88-1820.

59 GAK Corfu 123, 20 Apr 1842. There are cases in that were tried in the civil court where women sued or were sued over episodes like this one. I have, however, omitted all civil litigation from this study.

60 TNA: PRO CO 136/1275, 21 Sept 1821.

61 TNA: PRO CO 13/1283, 5 Dec 1838. 
In the summer of 2011 Athens was the site of fierce confrontations between Greeks and their political leadership (this curious envoy from the "cast of self-protective elites", in Perry Anderson's phrase, that has taken over the micromanagement of life in Europe); but also between Greeks' chronic delusions about their place in the world today and financial "reality" making Greece the unlikely epicentre of global economic instability. Greece's relations with the world have always been dynamic and fraught, but the uneasy way in which the country has recently come back again to be the sticking point of global attention has surprised many. The opening of two exhibitions in Athens, The Last Grand Tour and Polyglossia, which throw light on the highly intensive traffic between Greece and the western world, reminds us how tricky this contact has always been at the cultural level.' This traffic has been crucial for both ends of the itinerary: the Greek diaspora - Greeks living abroad - has been an inextricable part of Greece's emergence as a state right from its modern inception; ${ }^{2}$ and equally, Europe's collective identity as a cultural area was for long shaped through contact - i.e., travel, scholarly study, classical and anticlassical taste - with Italy and Greece.

The Last Grand Tour traces the physical trajectories as well as the cultural projections of western art travellers in twentieth-century Greece, while Polyglossia aspires to give us a slice of what it means to be a Greek living artist working in the West today. These exhibitions are only two examples of a growing interest in the notions of travel, mobility, nomadic and diasporic existence, deterritorialisation and global migration, and their role
In-N-Out Greece:

Cultural Tourism in

the Age of Diasporic Cultures

\section{Aris Sarafianos}

University of loannina 
in cultural practice and identity formation. And they both evince a strong sense of presentness, bringing these phenomena as close as possible to the contemporary world. However, the Last Grand Tour is a complex project with solid documentation and a specific historical and critical framework, while Polyglossia, which boasts of its "liberation" from history, seems to waver between a survey, which is explicitly not, and a thematic exhibition, which it does not want to be. Collectively, these exhibitions work to show the extensive networks of in-and-out mobility that, for better or worse, lie at the very root of Greece's historical formation like perhaps in no other western example. And they also, each in their own way, serve as a reminder that this country has long been and will continue to be so strangely passionate about openness to the world as well as about itself and its identity. A deeply rooted introversion and a well-concealed shyness go hand in hand in this country with an equally deep affection for otherness, producing an effect of almost dazzling opacity that has yet to be seriously studied.

\section{The Last Grand Tour}

"Tis Greece, but living Greece No more!"

— Lord Byron, The Giaour, 1813

The Byronic epigram heading Jessica Morgan's introduction to the catalogue of The Last Grand Tour is a curious signpost. It encapsulates what the show's curator tried to avoid - yet another historical exhibition about the romantics' fascination with antiquity marked by the absence of any meaningful "confrontation with the contemporary situation". But it also throws into relief what it strives to achieve, namely, a chart of the various "responses to the country" expressed by artists who "have lived and worked in Greece" during the twentieth century. The exhibition indeed explores how the country has "continued to be a source for artistic innovation". And yet when the surface of this notion of "country" is scratched, we again bump into the romantic fixation with its "long cultural history" or "geographic characteristics", and not exactly with the "living Greece" of the present. ${ }^{3}$ The confusion of aims and intentions regarding the larger question of the relations of contemporary culture with the ancient past, and, by extension, Greece, is encapsulated in the introduction's closing paragraph. This is where the exhibition purports, on the one hand, to show "how the role of ancient culture [has] changed in contemporary art" while, on the other, presuming quite the opposite, i.e., "the abandonment of classical heritage" (whose effects on "our future artistic surroundings" we are urged to consider). The confusion continues as the curator wonders "at what point did artists cease to travel to Greece for extended periods of time", although the show clearly proves they have not. Readers become even more perplexed as they learn, in the next sentence, that the show aims to bring "to light the striking shift in contemporary culture that has seemingly witnessed an end to the traditional 'Grand Tour"'. ${ }^{4}$ Whether this shift is "striking" (i.e., real and impressive) or "seeming" (virtual and misleading) cannot be resolved by sloppy formulations of this kind. Has it happened or not? Is it happening? Will it happen? Does it seem to be happening but never actually has? What is happening here?

Let's take things one at a time, and first, the critical question of how the show is framed by its poignant title. Strictly speaking, the tour in Greece was never part of the historical formation of 
the Grand Tour, which was predominantly an Italian phenomenon. This is something that the organisers seem to accept without, nevertheless, exploiting the significance of the many differences between the two types of cultural travel. ${ }^{5}$ As a growing number of recent publications on the sociology and cultural history of the Grand Tour indicates, the association of the Grand Tour with eighteenth-century Italy is not a phenomenon that can be, as the show implies, narrowed down to artists travelling to Italy in pursuit of artistic education or classical models. ${ }^{6}$ To a large extent, artists thronged to Italy as part of a crucial career step preconditioned by the presence of an influential network of collectors, art patrons, aristocrats, diplomats, dilettanti and connoisseurs of every description as well as art and antiquities dealers and archaeologists. In this context, Italy was for artists the ideal marketplace: liaising with art dealers, seeking lucrative clienteles and all types of employment (from archaeological excavations or conservation projects to art commissions) as well as setting up networks of polite patronage useful back in their countries of origin - Britain most frequently. The Grand Tour was also an experience, a stratified experience of rarefied sensations, tasteful contact with classical art precisely in the land where it had been produced, as well as being the vehicle of wilder and more sensual pleasures. From John Brewer's work - The Pleasures of the Imagination, most conspicuously - to numerous recent publications, scholars have looked into tons of private correspondence in order to describe the role of libertinism, sexual innuendo or ritualised debauchery in processes of male bonding among the Grand Tour elites and artists as well as analysing the political, social and professional implications of such interactions. ${ }^{7}$ Horace Walpole was expressing a common sentiment when he asserted that, as far as membership to the influential Society of Dilettanti was concerned, "the nominal qualification is having been in Italy, and the real one being drunk". ${ }^{8}$ The Grand Tour was a sensual as well as aesthetic, and predominantly a professional, social and political experience.

In all of these ways, the Grand Tour in its eighteenth-century Italian version was a centrally placed and heavily centralised experience with more or less solid structures, itineraries, networks, expectations and returns. It was power-driven and owned a crucial position in the commerce of power both for artists and their patrons. What does all this tell us about the Greek Tour towards the late eighteenth century and later? Certainly that it cannot be treated as a simple inclusion, extension or addition to the "traditional Grand Tour". The place was off the beaten track and it lacked the firm social networks, the internationalised power structures but also the polish, the chic and the rarefied ways of life associated with the Italian Grand Tour. Greece was no meeting point for social climbers either; it was a place for outsiders, as well as pioneers and adventurers of the elite, not exactly for connoisseurs and hangers-on in pursuit of vertu and good life; even less so, for artists in pursuit of polite patronage. It comes as no surprise that the Greek "Grand Tour" did not attract the likes of Anton Raphael Mengs, Gavin Hamilton, Jean-Dominique Ingres or Benjamin West: not even the young J.M.W. Turner thought it useful to follow Lord Elgin down to the Parthenon despite the latter's invitation. It was such characters as Feodor Ivanovitch (the Calmuck) and Giovanni Battista Lusieri, another outsider from Italy, who finally became Lord Elgin's "irregular" artists. ${ }^{9}$ Greece was a sober destination, and it is no coincidence that its symbolic entry into the Grand Tour is associated with the time when the members of the Society of Dilettanti finally decided to sober up a bit, lift their social profile and find a serious purpose for their "infamous" club: already on the lookout for a proper scientific project to associate themselves with, they grabbed the opportunity presented by James Stuart and Nicholas Revett's 
proposal for an archaeological expedition to the Parthenon - and testament to the success of the venture, they held on to similar projects in the area for decades to come. ${ }^{10}$ Again Greece was a place outside of the European public sphere, a place where one could hide, escape or die heroically, collect ethnographic curiosities or come back with rare pieces of authentic antiquities and antique experiences (Lord Elgin), but not a place exactly for networking and varnished lifestyles.

Such a historical framing of the discussion seems to be useful because it tells us something significant about the period and the group of art travellers relevant to the exhibition at hand. In other words, the historical notion of the Grand Tour may help draw a crucial distinction here between cultural travel as such (Greece) and cultural mobility as part of an established career structure for artists and others (Italy). Moreover, many of the artists included in the show sought in modern Greece a type of alienation, loss and abandon similar to that implied, in the minds of "romantic" visitors, by the ancient ruins, the frugality and the hardships of Ottoman and postOttoman Greece. There is a residual yet persistent "romanticism" in recent art travel to Greece, whose resilience throws more effectively into relief the radical transformations which it has in the meantime undergone.

What I mean is that in spite of the melancholy discernible in some of the most impressive work on display, this postmodern "romanticism" about Greece is an inverted and rather brutal romanticism at that. When Johann Joachim Winckelmann, for example, mourned the irretrievable loss

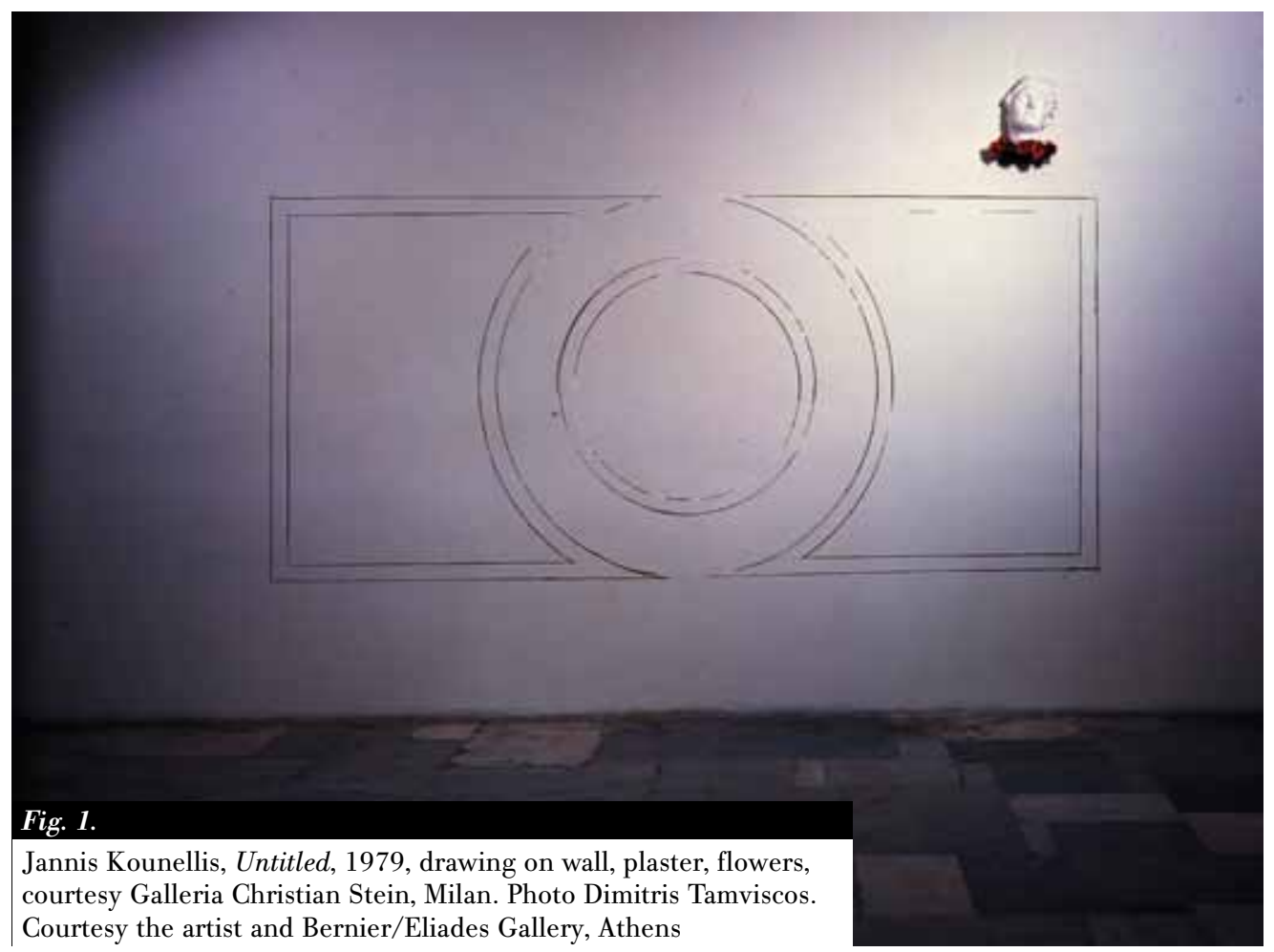


of antiquity through the figure of a tearful lover gazing at her "departing sweetheart" on a ship - who, like antiquity, left behind him nothing more than "a shadowy outline of the subject of our desires" - he had in mind a range of solid compensations and rewards for this loss. For Winckelmann, the loss of antiquity "arouses so much the greater longing for what is lost" and stimulates "greater attention" and study to retrieve and reconstruct it than "if we were in full possession" of it. ${ }^{11}$ No such productive nostalgia today: the artists on the show seem to revel in the sheer

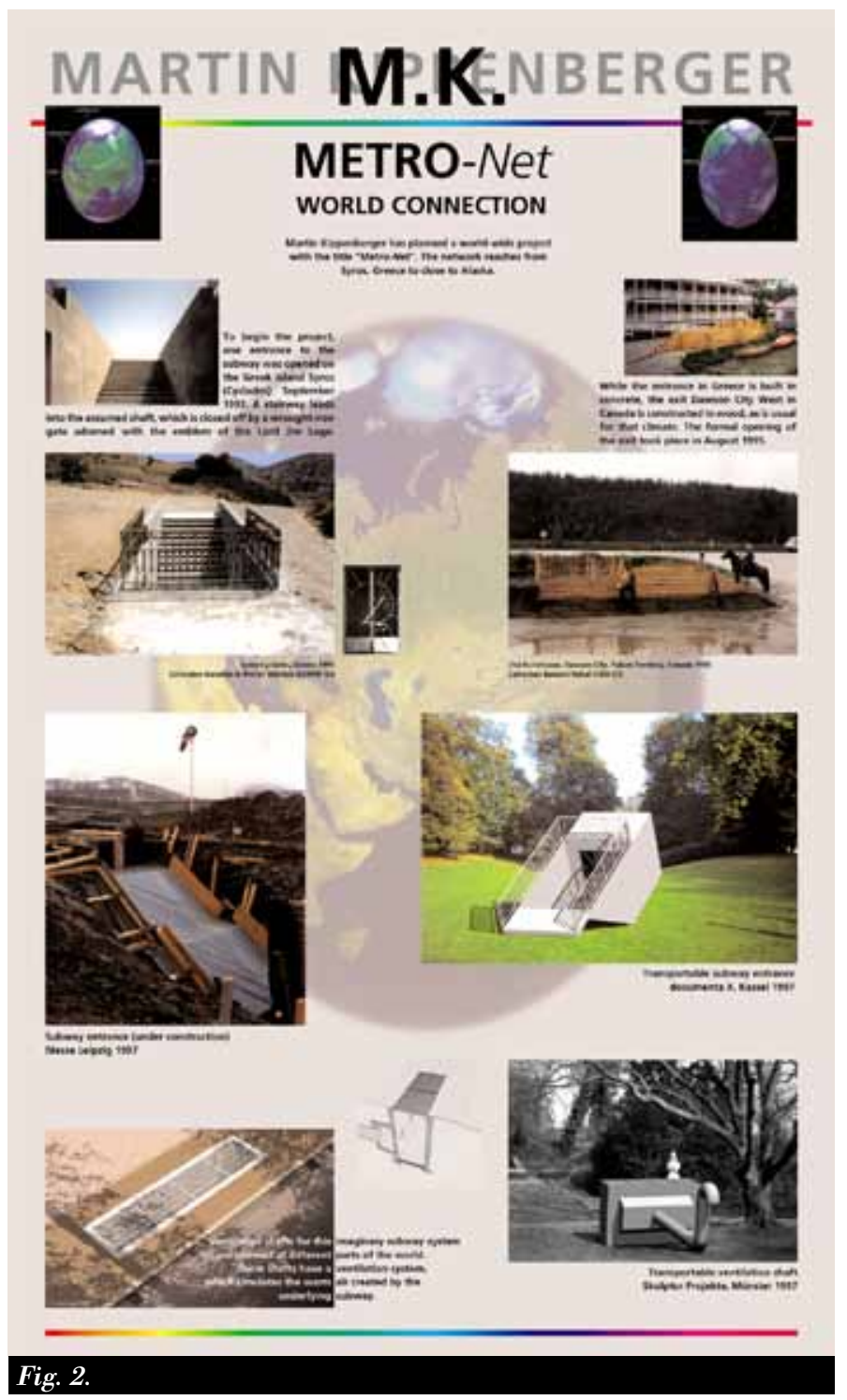

Martin Kippenberger, METRO-Net World Connection, 1997,

CAD print, designed by Lukas Baumewerd, 93 x $58 \mathrm{~cm}$.

Estate Martin Kippenberger, Galerie Gisela Capitain, Cologne.

Photo @ Estate Martin Kippenberger, Galerie Gisela Capitain, Cologne fact of the "lover's" departure. But make no mistake: their delight does not imply a simple "good riddance" to antiquity. Rather, their stance marks secret pleasures which have become the grand narrative of our postmodern times: delight in dispersals, disseminations, lacunae, evacuations, blockages and irretrievable absences.

The works by Jannis Kounellis and Martin Kippenberger selected for the show emblematise best, in my opinion, this curiously inverted nostalgia characteristic of the postmodern condition, namely a nostalgia for nostalgia, or, better still, the impossibility of being nostalgic anymore. Kounellis's Untitled (Fig. 1) consists of a wall drawing depicting the original gallery floor of the Bernier/ Eliades Gallery in which it was first shown in 1979, a classical sculptural head and underneath it a wreath of fresh anemones. The theme looks like an illustration of Winckelmann's words: according to the myth, anemones sprang 
from Aphrodite's tears as she mourned the death of Adonis. The utter minimalism of the empty gallery sketch drawn against the blank wall, together with the few classical symbols of mourning at beauty's death, construct a real chain of losses. In spite of the severe, classical simplicity of the whole - almost worthy of a low relief or a drawing by John Flaxman - Kounellis' evacuated signs of antiquity departing seem to signal the irretrievability of antiquity's disappearance. Unlike Winckelmann's tears which flooded, with fantasies of ideal beauty, hundreds of pages and thousands of feet of gallery spaces for two centuries, Aphrodite's tears are incapable of filling or supplementing the gap and absence they mourn.

The documents (drawings, models and posters) from Kippenberger's mock projects - MOMAS (Museum of Modern Art Syros) and Metro-Net (Syros) - invite similar readings: modern Greece serving as the workshop of an artist "working in the face of a "perceived death of painting".'12 Somehow the idea of placing in Syros the most lively among postmodern notions, that of the death of painting as well as the death of the author - both terms around which Kippenberger's work was built - is very poignant. For Kippenberger, contemporary art is motherless (with neither a geographical nor intellectual centre) and fatherless (with no authorial coherence or originality). What would then be the most rightful place to celebrate these fatal losses than the assumed birthplace of the arts itself? Syros/Greece thus becomes the location for an unlikely MOMA franchise in a derelict building in an empty plot of land, as well as being the site for the lonely entrance to an impossible global underground network that takes no one anywhere (Fig. 2). This is the most Greekless work done in Greece present in the show. Kippenberger's mode of engagement with Greece is pure topography (Syros): no traces, no Greece-related motifs, themes, experiences or classicising titles. Greece is the ideal place for a process of evacuation of cultural signs whose radicalism was announced decades ago as the technique par excellence of radical practice ${ }^{13}$ - in this case, the emptying out of the sign of "art". Though I strongly doubt how relevant for a truly subversive cultural practice Roland Barthes's proposal may still be, there is much to be admired in Kippenberger's cold, ruthless, joyous and self-generating ironies. Even more ironically, Kippenberger's gay science of dissemination highlights once again how fine the line between the sublime and the ridiculous may actually be: its uneasy proximity in the show to the facile ironies of Juergen Teller and Manfred Pernice underscores again how difficult it is to keep irony and deconstruction from sliding into silliness.

Yet perhaps the centre of gravity of the exhibition is Cy Twombly's work, as it is perfectly placed in the show to mark the passage from an older generation of art travellers with their own humanist responses to Greece as a postclassical site, to the work of contemporary artists, reviewed above. Twombly's Delian Odes series reveals the same savage stroke-play and scruffiness of markmaking, the same palsied but highly recognisable graphic and writing style for which he became known. But it also reveals a "wish to expose himself to the world as it happens, as it impinges on the passive senses" and an "aesthetic intensity [which] is bound up with haphazardness", with precarious and faltering encounters with the world. With the world, and "not with painting", "the aleatory or the uncentred or the il n'y pas de hors-texte - or any such big idea" as T.J. Clark explained in his most recent review of Twombly's show at the Dulwich Gallery which coincided with the artist's death in July 2011. ${ }^{14}$ Twombly's work signals, for Clark, the return to the pressure and teeth of the senses, and his double interpretation is very apt in the context of the present show, insofar 
as it also seems to play with the idea that there may be two different approaches to Greece which are coextensive with larger shifts in art languages over the last 80 years.

In other words, for Barbara Hepworth, John Craxton or even Ben Nicholson - an earlier generation of artists who came to Greece in pursuit of a revitalised classical tradition more in tune with modernist innovations - the Enlightenment languages of sympathy and sensibility were still alive. Their sensuous experience of the Greek landscape belongs to a long tradition of experiment and experience, for which aesthetics was tied up with aesthesis understood as a material and sensorial engagement with the environment. And their work on display reminds us that Greece had also been the site for a high-minded dilettantism of everyday life, and for a smart tourism of refined sensibilities. Coexisting uneasily with the anxieties of postmodernist criticism, this tradition is not dead yet. The show aptly includes the work of a younger generation of artists equally hungry for site-specific affects and sensorial particulars (forms, colours, sensations collected from their immediate surroundings). Brice Marden's marble paintings - pieces of broken stone with oil and graphite patterning - represent a successful example of what contemporary art can do with the legacy of sensibility on ancient grounds (Fig. 3). The rough edges and subtle surface textures of Marden's broken stones initiate a gentle dialogue between soft and hard matter, artist's body and nature's stones, animate and inanimate orders of sensibility, which is very entertaining. Addressing a rather different section in the spectrum of sensations and emotions, Helmut Middendorf's A2 acquires a particular resonance in Greece: this dark response to the dystopian cityscape of Athens dominated by a sprawling knitwork of tightly woven concrete structures offers a humbling retort to the classical utopia of order symbolised by the architecture of ancient Athens. Marden and Middendorf together revive a notion of the artist as a sensitive medium between the corporeal reality of the sensorium and the materiality of the artwork, an ideal that Twombly never lost sight of.

The organisers must have good yet undisclosed reasons for the inclusion in this show of three artists of the Greek diaspora. A Grand Tour around one's own country, which amounts to being a tourist in one's own "homeland", is not inconceivable - more than half of the Greek population, packed in two metropolitan areas as they have been for decades, are strangers in their own country and conceivably deserve the name of tourists as much, if not more, as anybody else. But still in terms of identity - social, ethnic as well as professional - there are many meaningful ways in which a Greek art tourist in Greece, and especially those of the Greek diaspora with their own very complex baggage of

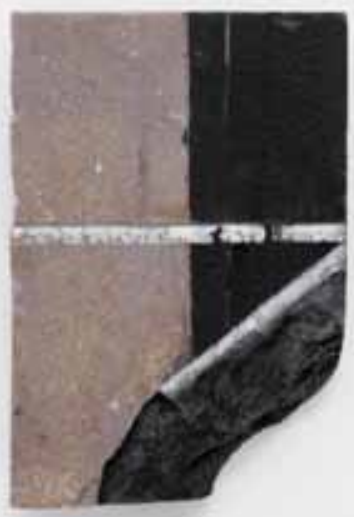

\section{Fig. 3 .}

Brice Marden, Marble \#13, 1981-83, oil and graphite on marble, $25 \times 17 \times 3 \mathrm{~cm}$.

(C) Brice Marden/Artists' Rights Society (ARS),

New York. Courtesy Matthew Marks Gallery,

New York. Photo Bill Jacobson 
suspended memories, regurgitated emotions and persisting associations, could be more advantageously distinguished from other cultural tourists. The inclusion of Lucas Samaras, in particular, will have to remain an enigma: the artist's photographic self-portraits, entirely taken and manipulated in Samaras' apartment in New York, do not exactly constitute travel in Greece except in the overly metaphorical sense of "a personal journey" back to his Greek roots. In the same sense, Samaras' project fits much better the quite different remit of how a Greek travelling abroad negotiates his unresolved sense of self, ethnic identity and memory - admittedly an interesting discussion that belongs to another exhibition like Polyglossia, which should have started it but never did.

Daniel Spoerri is the real star of the entire show and the organisers rightly let his work assume a vital place as it draws together the many different possibilities of representing Greece revealed by the exhibition. The show includes 20 out of a group of 25 "archaeological objects" which constitute his "magic à la noix" series ${ }^{15}$ made during his stay on Symi in 1966-67. These objects are bricolages and assemblages made out of flotsam, stones, dried plants, animal bones, local junk and cooking leftovers in combinations adjusted together by hundreds of feet of wire, cord and rope. The inclusion in the exhibition catalogue of a 76-page booklet - a facsimile reproduction of an extract from Spoerri's book Mythological Travels (1970) where the artist explains the quirky yet precise biography of each of the objects on display - is a real treat. ${ }^{16}$ This supplement is necessary documentation - wrongly missing from other works, especially lannis Xenakis' multidisciplinary work which was unfortunately treated as another multimedia piece of visual art. For Spoerri, the precise biography of his objects, i.e., the stories and descriptions about the circumstances of their discovery and the memories or affects they elicit, are as important as the works themselves: narratives wind around the objects like the actual cords and strings with which they are ceaselessly wrapped.

To be sure, Spoerri's method takes into account the visual and material details of the different pieces to be joined together into the final art objects: form, colour and consistency, or "such and such a crack or curve, this colour or that surface [which] demands to be joined to another" (38). But the pieces are held together by dint of "the relations which attach to them", namely, through webs of interlacing thoughts, stories, memories, free associations and experiences. Both processes (which he called his "magic à la noix" method) aim to make his objects "unique", they are both processes of isolation and singularisation of the quotidian: if in the former process uniqueness is dependent on sensorial singularity, in the latter an object "becomes unique because of its history" (38-39). This is what the booklet supplies - and much more besides: the life-stories of objects. Interestingly enough, this historical process is also seen by Spoerri as a process of "concretising an emotion" which he also eloquently calls "psychological and affective" $(5,38)$. The important novelty of Spoerri's histories of objects is that they redefine history as a field filled with affects, emotive memory, chance encounters, accumulations of concrete materials as well as ceaseless miracles of discovery - you bump into history, you don't exactly look for it, or, history finds you in a way always astonishing, unpredictable and yet unavoidable.

Spoerri's "archaeological museum of Symi" hits on something equally interesting for archaeology too: long before talk of whether we have ever been modern, or how ancient moderns truly are, had become fashionable in history of science circles, Spoerri reversed and problematised the all too "modern" polarity of antiquity versus modernity..$^{17}$ Together with another artist, Fran- 
cis Bacon, he would ascertain that "these times are the ancient times, when the world is ancient, and not those which we account ancient ordine retrogrado, by a computation backward from ourselves". But, at the same time, he would defend the modernity of his "archaeological museum" comparing it to "real archaeological museums" on the grounds that they are both "just as full of refuse from the garbage cans of the modern times of ancient times that an accident of magic à la noix caused to be discovered" (76, 69). Accordingly, his Neolithic Colt (object 24) (Fig. 4), a long and thick bone from an ass readjusted into a weapon, is more modern than the Colt Jesse James used to kill his victims by virtue of the sheer fact that it is ancient, and every antiquity has its own immanent and still more powerful modernity embedded in it.

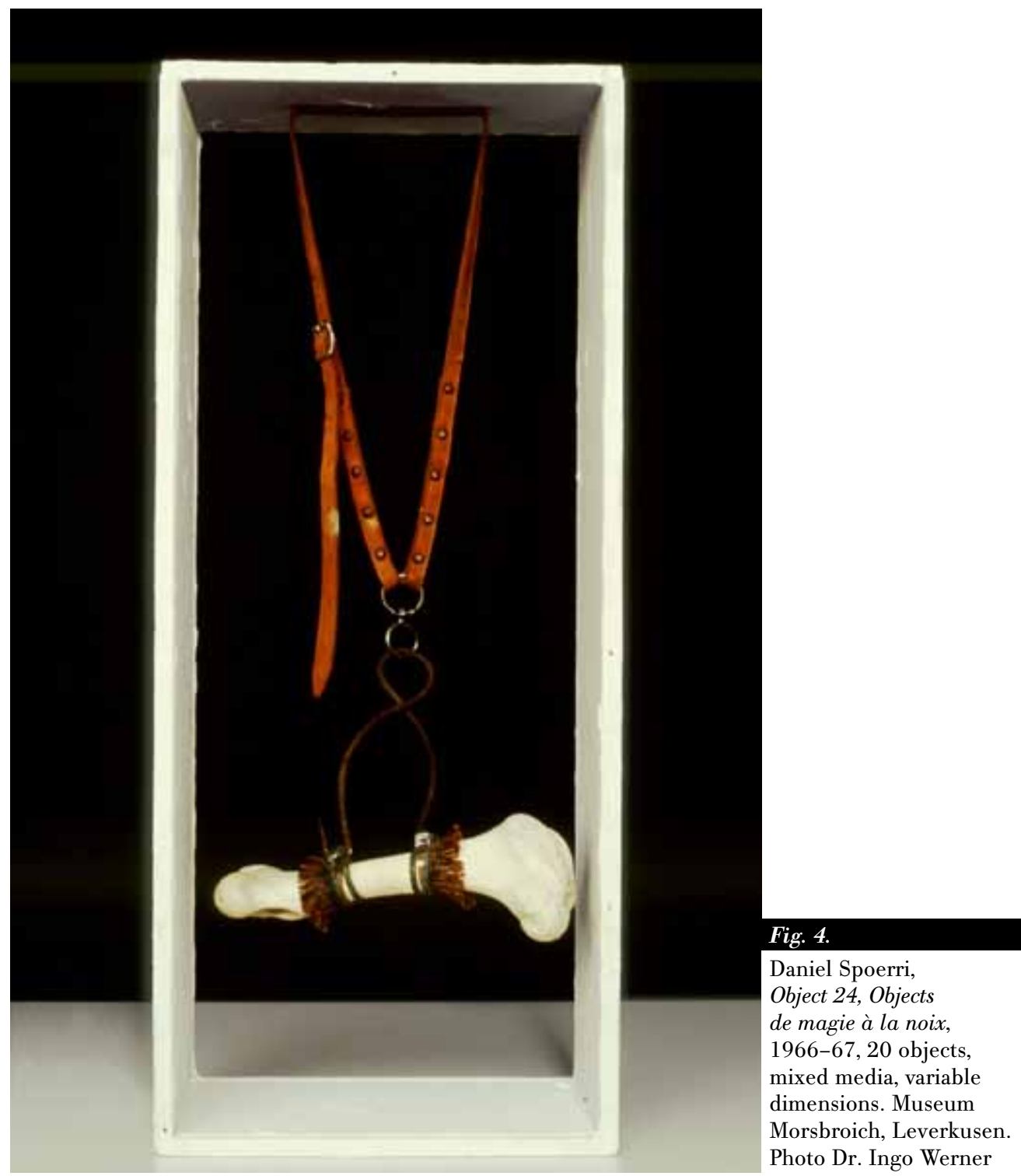


In the booklet, oscillation between such polarities is a grand theme: Spoerri's objects are continually tangled up in philosophical meditations about the antitheses of inside/outside, container and the contained, form and content, or left and right, viewer and spectacle, or artist and viewer, height and weight, two-dimensional canvas and three-dimensional space, and, ultimately, present and past. What is even more fascinating, though, is that Spoerri himself placed his Symi experience at the very centre of his prolonged struggles with the nagging notion of contradictions. This raises an issue most relevant to the show's theme: the place of Greece in Spoerri's objects. The exhilarating thing about a question like this is that for once it doesn't seem to emerge as an external, reductive or projected concern of scholars or artists obsessed with common topoi and fixed ideas about Greece. If there is something culturally meaningful about Spoerri's artistic involvement with Greece, this is inherent in it, especially insofar as his art objects emerge at the point where the biography of the artist - as a cumulative and uncontrollable experience of purposeless searches and past memories - intersects with the space, soil, matter and junk of his place of work. It is in the nature of Spoerri's archaeological-cum-historical objects, as a condition of their making and circulation, to be site-specific, vernacular, singular and quotidian, that is, to emerge out of and carry with them the spatial and temporal marks of their chance occurrence. These objects are made singular and unique as a consequence of being of the place in the most literal of all senses, packed as they are with the local experience of time and space: they are dug out of the soil or collected from the place's most "historical" of spots (piles of debris, garbage cans, derelict houses, etc). Junk objects like those collected by Spoerri are historical and contextridden markers of a new haphard sense of age-value - bearing in their cracks, erosions, scars and other damage the accumulation, usage, messiness and vicissitudes of the passage of time.

Unsurprisingly, therefore, there is, in Spoerri's narration, a perpetual exchange between his art practices and the island. Symi, for Spoerri, is like the objects he produces, wrapped and warped with endless cords of affective associations. Moreover, there is a slippage at work between the island and the country: object 25, a handful of earth from the "Paradise" of Symi, is "enshrined in a can stamped “Greece'” (74). The "grand object” Symi/Greece makes several appearances in Spoerri's descriptions of his 25 smaller objects worth further attention. Firstly, Symi supplied Spoerri with "a brutal and extreme nature" (6) where stories of cruelty abound. Spoerri's object biographies go back regularly to his personal sadistic fascination with the admittedly savage processes involved in the preparation and cooking of lobsters as well as to the Symians' collective propensity to cruelty, best expressed in the viciously slow killing of rats by locals $(35,21)$. But stories of primordial bliss and prehistoric beauty also recur in Spoerri's Symi chronicle, evoking a certain pastoral and sentimental interpretation of the place $(42-43,46)$. Symi features as a kind of "paradise", part of "the cycle of nature", "the kingdom of the naïve", full of natives unappreciative of Spoerri's art. Indeed, there is often a recognisable tone of haughtiness and cultural arrogance in Spoerri's accounts, which rises sometimes to the point of being irritating. The same arrogance transpires from Spoerri's stance towards the historical reality around him (20). To put it briefly, Symi/Greece resembles equally the primitivist utopia of a sadist and the blissful paradise of a snob.

Notwithstanding such guises, Spoerri's Symi/Greece remains a place radically removed from the metropolitan West. Some may be inclined to use such blanket terms as "exoticism" or "escapism", or even "orientalism" to describe similar kinds of stance. The real point, however, is 
that, in Spoerri's case, Greece emerges not just like a place of the periphery but something like a peripheral spot which is simultaneously the antipodean site and the ancient black hole, where the "centre" (the West) and its fashionable modernities are swallowed and thrown up again in unpredictably creative ways. It is fascinating, for example, that Spoerri arrived at Symi with specific expectations about the potential role the island could play in the development of his art. As he contends in the introduction to his book, he "came to the island of Symi" so that here, "on paths trodden only by donkeys", he would "be able to think" his magic à la noix method more advantageously (6-7). As he explains, it was "here at Symi, [that] I thought I was ready" for the "experience" of "expressing [myself] in two dimensions"; namely, of regressing back to painting and reclaiming the canvas (the "flat surface") as a field of expression. More importantly, however, it was "here at Symi" again that he did not only give up for good this "regressive" idea that had "always troubled" him, but also transformed it into something sufficiently new (19-20). Object 6 is the head of a spiny lobster wrapped with a square of linen which is precisely the canvas on which he never painted. In this sense, Symi/Greece seems to be the ideal ground for the dramatisation of contradiction, encouraging both the expression of primordial fears and their sweeping overcoming in an art object which held a special position in the evolution of Spoerri's technique: as he confessed, Symi was the place "where I wrapped up, until it was invisible, the first object that filled me with fear, the needle swallowed by a goat, causing its death, which I found while cutting a slice of liver [object 5], as well as the head of a goat that I had seen while it was still alive [object 4], and the tail of a rat guillotined in a trap [object 11]" (6). Spoerri here described his almost compulsive technique of covering and preserving objects in hundreds of metres of cord. In short, the primitive brutality of Symi/Greece gave birth to an irresistible fear which then led to a grateful compulsion with artistic implications - wire trappings and wrappings ad infinitum.

Trouble in paradise, indeed. Spoerri supplies another version of a quotidian, visceral and chthonic "Et in Arcadia Ego", digging from the opposite direction to meet Cy Twombly's Delian and other artistic "Arcadias".

Furthermore, as already intimated, Spoerri also placed Symi/Greece at the centre of his important confrontations with the nature of contradictions. Spoerri's Symi/Greece is indeed the site where the persistence of contradictions becomes both more inevitable and clearer; where contradictions surface to consciousness more pressingly but also with the lucidity necessary to question traditional perceptions about them. His Symi experience features high in his attempt to question the banality of western dualism - dualistic philosophies of good and evil, of heaven and hell, of right and left, etc. Object 14, another assemblage of shoe, wire and bones, seeks to overcome this dualism by imagining a uniped bodily existence (one leg, one shoe, one arm) to go beyond all schisms (Fig. 5). In Spoerri's criticism of dualism there is a deep acceptance of contradiction as an engine of affect and knowledge, an attitude to it which, as I have elsewhere shown, far predates his reflections and forms the basis of modern definitions of the sublime. ${ }^{18}$ This is how Spoerri explained the critical contribution of Symi/Greece in his own theory of contradiction aptly expressed in object 14: "And why are we condemned to cast these agreeable traditions [of contradiction] in doubt on a garbage dump on a forgotten, rock-bound Greek island? Because it is precisely there that we lose contact with the indispensable extreme that makes a left shoe a left, and a right a right. There ... I love odd shoes" (27). Meaning? That, in Spoerri's 


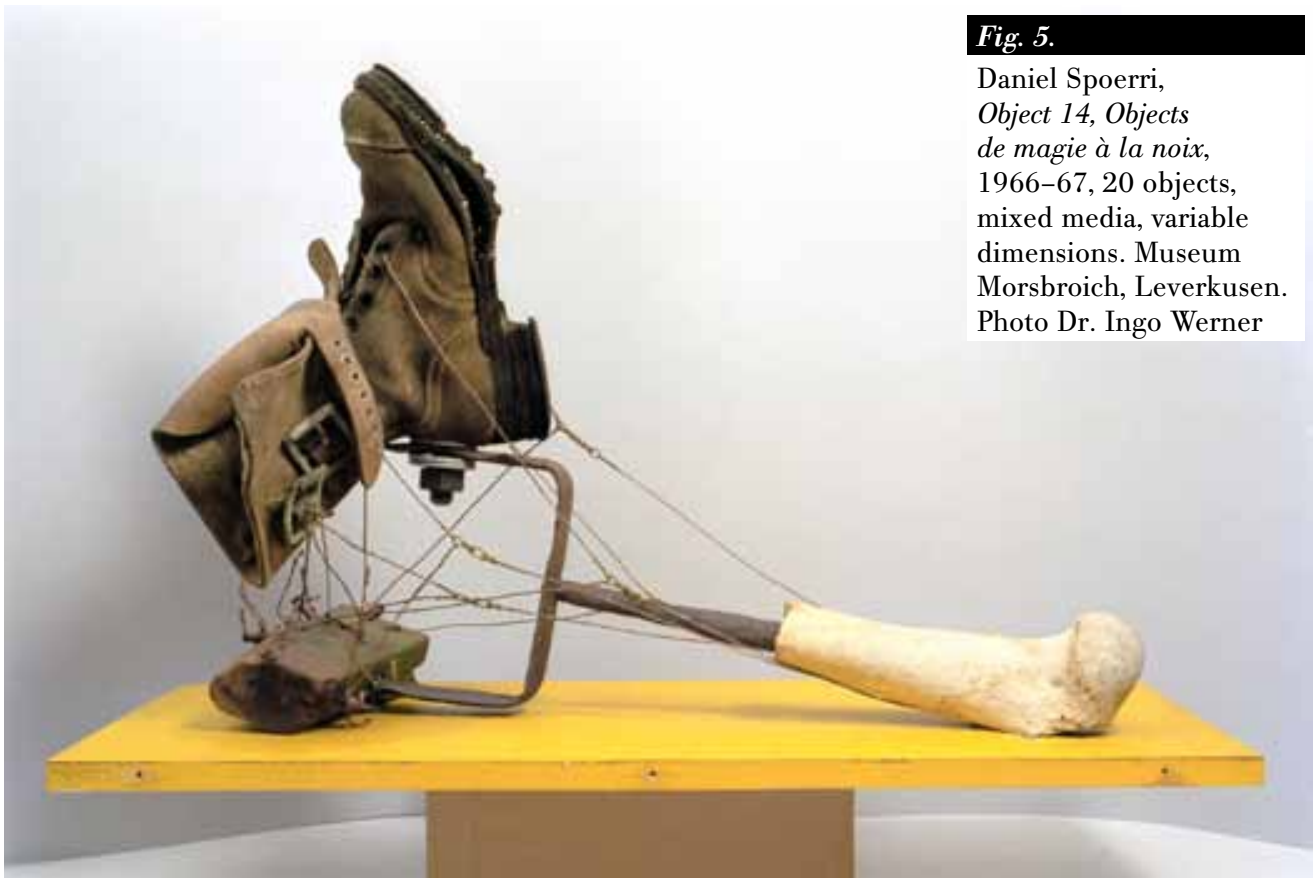

Symi, we are not anymore, according to the logic of dualism, obliged to identify with either this or the other side of a given polarity. Rather, what matters now is the bipolar passage across the antithetical extremes. In fact, his Symi/Greece discovery of the cord-wrapping technique mentioned above was placed in the same context of overcoming dualistic perceptions of the contradiction between form and content: "it is between the poles of the inseparability of the two that my anxiety at not finding a definite solution will oscillate, which could be interpreted positively as the desire for instability and change" (7). His cord-and-wire-covered objects reincorporate contradiction by re-enacting the ultimate proximity and rapid oscillation between the extremes of container (cord) and contained (the pieces of which his objects consist). No dialectics and no closure, no resolution and, of course, no dualism here: just a perpetual endorsement of states of aggravated motion between opposites - contradiction at its most sublime.

To conclude: Spoerri's work hits at the centre of a long alternative tradition of representations of Greece which he upgraded in fascinating ways. This is a Greece fantasised but also experienced as a marginal space, a place of violent, stimulating and productive insulation existing in meaningful contrast with more refined destinations of western travellers as Italy..$^{19}$ But again there is also a radical distinction to be drawn between different attitudes of alienation, which this show also implies. There is, for example, something naïve about Leonard Cohen's escapism or even Craxton's pastorals also included in the exhibition: the latter came to Greece because he "sought for an alien land [to] see if my talent would stand it", while Cohen got gradually more depressed in Hydra because it could not anymore sustain his delusions that he would be "able to escape after all" from "civilisation". ${ }^{20}$ 
As I have sought to show, Spoerri's arrogant quirkiness rests on but, simultaneously, goes far beyond such easy fantasies and pleasures of alienation. Further still, it is through his odd method of "magic à la noix" that a certain concrete relation to a sense of cultural environment is most paradoxically re-established, embedding art practice into a context which is still alive. Alive in the sense that this context is about living, eating, dying and discovering in a specific place with a distinct yet undeterminable affective and sensory footprint.

Oddly, it is such material, microhistorical and unpredictable engagements with the context of artistic production that are spectacularly missing in another show in Athens, where one would normally expect to find such engagements in abundance.

\section{Polyglossia}

HAMLET Madam, how like you this play?

QUEEN The lady doth protest too much, methinks.

- Hamlet, Act 3, scene 2, 222-230

Polyglossia deals with the work of Greek artists who have lived the greatest part of their lives abroad. Such an angle could bring into focus not just the creative implications of travelling surveyed by the Last Grand Tour, but actually what it also means, culturally speaking, to live and work abroad as an artist. And yet, for the organisers of Polyglossia, it seems that such long-term residence obliterates instead of increases the urgency to situate art production in the cultural and social environments in which they are embedded. Comparing the approaches adopted by the two exhibitions, Spoerri's six-month stay in Greece is revealed to be somehow more relevant to his art than Chryssa's life-long existence in the US. History, context, identity, subjectivity, ethnicity and gender - all concerns which are at the very forefront of every study examining the influential notion of diaspora in contemporary art practices - are proudly waived aside. The catalogue introduction is a list of denials: the organisers insist that they were interested in providing neither a complete survey of Greeks abroad nor any basis for a discussion of the phenomenon of diaspora in historical terms. Even more surprisingly, critical engagement with questions of ethnicity features as a taboo, immersed in the organisers' worry that they may in this way be stirring up the admittedly worn-out theme of seeking the elemental Greekness in the work of Greek artists abroad!!1 This is a seminal example of throwing the baby out with the bathwater, if there could ever be one - especially insofar as the field of diaspora studies is concerned.

First of all, this is just an unconvincing way of doing cosmopolitanism today - evidently the organisers' precious wish. As I have shown on another occasion, cosmopolitanism, historically, draws its force and persuasion from its serious engagements with the ideas (and affects) of nationhood and ethnicity. ${ }^{22}$ Secondly, such an approach to a show whose, perhaps, most visible theme is the life and circumstances of artists living abroad demonstrates an unenviable ignorance of how similar studies are conducted today in the broader field of academic writing. The kind of historico-critical method cultivated successfully in recent art biographies such as Caroline Jones' book about the life of the New York art critic Clement Greenberg seems like a distant future for this type of art curating. ${ }^{23}$ Although art biography is being reinvented as a genre of microhistory pertaining directly 
to the study of the crucial role that everyday sensory input plays in re-programming (aesthetic) subjectivities, Polyglossia refuses to engage.

This would all be less irritating if such a shift to diluted forms of cultural theory was accompanied by some rigorous outcomes. By contrast, the result frequently defeats itself as in the case of Greekness which, in spite of the said protestations, is actually at the heart of the show. The organisers indeed developed the idea of the present display of Greek diaspora artists as a result of the intention of the board of trustees of the Onassis Foundation to promote the work of primarily Greek artists. Greek nationality or Greek origins are acceptable, but not the study of Greekness as a force field of memories, affects, real and imagined ties. The Spoerrian - unpredictable, associative and historical - Greekness of many of these Greeks abroad becomes just "Greek"; namely, a brand, a mark, an institutional inscription as culturally empty as any entry of citizenship in a passport. Of course, the introduction declares a tokenist interest in investigating the processes of international osmosis or interaction between the Greek origins of artists and "the different cultural conditions, impressions and experiences gained in the different countries of their choice". ${ }^{44}$ But such declarations are nowhere actually pursued in the show or the specific catalogue entries of the works on display. In order to observe processes of interaction, you normally need both an acting agent (a new country and a new cultural system), as well as a clear notion of that which is acted upon (the "Greek" in question); but both are spectacularly missing from the show.

Polyglossia's actual enemy is history, specificity and context, namely, the particulars of language, thought, feeling, speaking, acting and, ultimately, the minutiae of change and permutation. To be sure, the cities and countries of the world where the Greek diaspora found its artistic home are equally suspended in a context-free vacuum. Places and cities are floating signs or digits, empty signifiers seeking a meaningful identity like the empty shell of the notion of "Greek". Leafing through the catalogue in pursuit of the exhibition's point, it struck me suddenly that the message of the whole thing may be precisely hidden in a digital code, where 0 is Paris $(P)$ and 1 perhaps New York (NY), with certain pauses and interferences represented by other city "bytes": Berlin (B), London (L), Amsterdam (A) and others. The following sequence, which replicates the order in which each artist appeared in the catalogue combined with their places of residence, is perhaps the closest the show got to offering visitors a platform for further reflection:

$N Y-P-P-P-N Y-P-P-N Y-[R o m e]-N Y-[$ Washington] - NY - NY - P - L - NY - NY [Rotterdam] $-\mathrm{L}-\mathrm{B}-\mathrm{L}-\mathrm{P}-\mathrm{B}-\mathrm{B}-\mathrm{B}-\mathrm{B}-[$ Palo Alto] $-\mathrm{A}-\mathrm{A}$

Or alternatively, one can go away, if they prefer, with the following equally vacuous tautology: different Greeks of the diaspora spoke different languages and produced variable work according to the varying conditions of the different countries they lived in. . .

The same mystifying discrepancy recurs also between the catalogue essays and the material on display. The essays by themselves are very entertaining, selected purposefully to give a veneer of multidisciplinarity to the whole venture. The writers did their best, but the fact that no firm relation is established between the essays and the show does not seem to be their fault. The star 
of the collection and perhaps the friendlier to the message of the exhibition is the little poem/ story The Other Babel told by the famous children's book writer Eugene Trivizas. The rest of the essays occasionally reveal a certain anxiety about the basic admissions and guiding principles of the show's curators. This adds substantially to their interest. ${ }^{25}$ Perhaps, Konstantinos Arvanitakis' psychoanalytical genealogy of art epitomises best the show's unfulfilled potential. Not only does he return to the questions of subjectivity which the curators avoided, but he pinpoints the critical importance of processes of identity formation specific to diasporic subjectivities, which the show has failed to acknowledge:

In his attempt to tame, or in other words, heal [the ontological trauma] the artist represents it (mimesis). In those cases where reality itself enacts in dramatic fashion and in a most tangible manner the primal ontological break, as for example in those cases where an artist has lived in two (or more) different cultures, this ontological break is more visible, its weight considerable and its role in the formation of an artist's creativity much more critical. ${ }^{26}$

Such useful cues are never pursued in the art-related section of the catalogue, and the absence of art historians from the line-up of contributors to the catalogue is indeed stunning. The entries next to each of the works reproduced in the catalogue do not deal with the specific concatenations of places and practitioners in each of the cases involved, unless they are occasionally written by the artists themselves. This material as well as artists' statements and interviews quoted in the press coverage of the exhibition frequently show that the questions of ethnicity, hybridity, locality and exchange are very relevant to them. The very useful biographical notes at the back of the catalogue raise similar connections and reveal that the artists themselves, as living subjects of diasporic lives but also as smart manufacturers of their hybrid identities, are extremely sensitive to similar questions. In fact, I believe that this is where the catalogue as well as the whole exhibition should have started from. This is because here emerge regularities and divergences which, at last, can be clustered into meaningful groups.

I will close by giving a hint of the research possibilities opened at this juncture. The artists' bios reveal, for example, multiple relations to cultural Space: different places of birth, variable places of education and art training, and numerous places of artistic residence. There is, for example, those who were born and raised abroad with the fantasy of their local community's Greekness (Lynda Benglis or Steve Giannakos), those for whom Greece was a childhood memory broken by early immigration to the US or elsewhere (Stephen Antonakos or Lucas Samaras), or again those who were raised in this country but trained and matured professionally in the West (Chryssa, Athena Tacha, Tzeni Marketou). However, the most numerous group of artists in the show was born, raised, educated and trained in the Greek public university system before they built successful careers abroad. This must certainly be another timely reminder of the much reviled failures of Greek academia. . . This diversity of place can also be further explored in relation to different generational patterns: various types of historical pressures led different generations of artists to different types of immigration abroad with distinct types of diasporic existence. This is the kind of meaningful multiplicity that needs to be studied as to its probable artistic implications. Further still, such plurality is further enriched by the parameter of Time, the temporal patterns cutting across such trajectories of spatial dissemination of artists. The length of residence 
abroad matters as much as the mode of its interruptions. Moreover, patterns of return to Greece, or oscillation between countries, are as important as the various degrees of temporal/spatial distance that each artist decided to take from his/her past. The variability in this respect is indeed exciting and very promising. And this brings us to the even more intricate question of Relations. By this term, I mean the whole economy of cultural references in the work of diaspora artists, or, in other words, the complex distribution of their attention across the split spheres of their experience. Diaspora artists fold in themselves and their productions different relations to the complex experiences of ethnic memory and cultural identity. And in a world of increasingly nomadic and deterritorialised lives, such concerns have become among the trendiest fields of artistic practice, as artists continuously reclaim, repackage and remarket; enrich, hybridise and politicise; or again challenge, block, or even transcend their ethnic and cultural predeterminations. Other kinds of concerns also matter: what are, for example, the variable channels of communication, or the aspirations and the investments implicit in the decision by a Greek collection or a Greek gallery - private or public - to feature and promote work from an artist of the Greek diaspora? The catalogue's bios trace singular and complex patterns of synergy between diasporic artists and the Greek art market which, in a period of increasing public and academic interest in the workings and the history of art collecting and display, offer rewarding lines of further research.

It is such working frameworks that may allow the cultural study of the Greek diaspora to reclaim its lost richness, historically meaningful sense of specificity and its paradigmatic value; or, in a language that Polyglossia management might better understand, its much-neglected comparative advantage over other research agendas in the highly competitive international markets of knowledge. 


\section{NOTES}

1 The Last Grand Tour, exhibition curated by Jessica Morgan, Museum of Cycladic Art, Athens, 15 April-10 October 2011, and Polyglossia, exhibition curated by Marilena B. Karra, Onassis Cultural Centre, MarchJune 2011. Important catalogues have also been issued to accompany the shows: The Last Grand Tour, exhibition catalogue, Athens: Museum of Cycladic Art - Nicholas and Dolly Goulandris Foundation, 2011, and Polyglossia, exhibition catalogue, Athens: Onassis Cultural Centre, 2011.

2 A small group of historians of modern Greece have produced pioneering studies in this direction. See, for example, George Dertilis, lotopía tou EMnvikoú Kpátous 1830-1920 [The history of the Greek state,

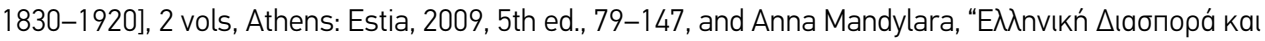

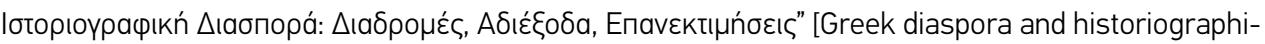
cal diaspora: trajectories, deadlocks, revaluations], Mnimon 22 (2000), 239-246. However, cultural and especially art historians in Greece have been largely absent from this discussion.

3 The Last Grand Tour, 14-17, esp. 14.

4 Ibid., 17.

5 Interest in the Grand Tour was rekindled by Ilaria Bignamini's historic exhibition at the Tate - see the exhibition's catalogue: Andrew Wilton and Ilaria Bignamini (eds), Grand Tour: The Lure of Italy in the Eighteenth Century, London: Tate Gallery, 1996 - and culminated right before her premature death with the impressive study of art commerce in Italy, in Ilaria Bignamini and Clare Hornsby, Digging and Dealing in Eighteenth Century Rome, 2 vols, New Haven and London: Yale UP, 2010.

6 Viccy Coltman, Fabricating the Antique: Neoclassicism in Britain, 1760-1800, Chicago: Chicago UP, 2006.

7 John Brewer, The Pleasures of the Imagination: English Culture in the Eighteenth Century, New York: Farrar, Straus \& Giroux, 1997; Viccy Coltman, Classical Sculpture and Culture of Collecting in Britain since 1760, Oxford: Oxford UP, 2009, esp. chaps 5 (“The Lecture on Venus's Arse") and 7 ("Casting a Lustful Eye"). The Getty Villa exhibition, Grecian Taste and Roman Spirit: The Society of Dilettanti (7 Aug-27 Oct 2008) co-curated by Bruce Redford, was an impressive study of the irreverent aspects of the taste for the antique. See Bruce Redford, Dilettanti: The Antic and the Antique in Eighteenth-Century England, Los Angeles: J. Paul Getty Museum and Getty Research Institute, 2008. See also Jason M. Kelly, The Society of Dilettanti: Archaeology and Identity in the British Enlightenment, New Haven and London: Yale UP, 2009.

8 Walpole to Horace Mann, 14 Apr 1743, Walpole Correspondence, vol. 18, ed. W. S. Lewis, New Haven: Yale UP, 1980, 211.

9 William St Clair, Lord Elgin and the Marbles, Oxford: Oxford UP, 1998, 24-27. For Lord Elgin's bizarre entourage of artists and their patchy yet fascinating output of architectural drawings, see also Luciana Gallo, Lord Elgin and Ancient Greek Architecture: The Elgin Drawings at the British Museum, Cambridge: Cambridge UP, 2009, esp. 18-51. Ivanovitch's extended corpus of sculptural sketches and drawings from his sojourn at Athens, especially of the Parthenon Sculptures, is held at the British Museum and still remains to be fully and independently assessed.

10 Kelly, Dilettanti, 145-71. For the Ionian expedition, see 172-194

11 Johann Joachim Winckelmann, History of the Art of Antiquity, intro. Alex Potts, trans. Harry Francis Mallgrave, Los Angeles: Getty, 2006, 351.

12 The Last Grand Tour, 40.

13 Roland Barthes, "The Reality Effect", in The Rustle of Language, trans. Richard Howard, Oxford: Black- 


\section{Interventions}

well, 1986, 141-148.

14 T. J. Clark, “At Dulwich”, London Review of Books, 25 Aug 2011, 24-25.

15 In referring to Spoerri's "Magie a la noix", I followed the English translation of the term by his friend, the American poet Emmet Williams. His choice is very convincingly explained in a footnote (see p. 5 of the booklet).

16 The booklet is titled Preserves of Magic a la Noix: 25 Archaeological objects of and by Daniel Spoerri and page numbers in the text follow the numbering of the facsimile.

17 Bruno Latour, We Have Never Been Modern, Harlow: Prentice Hall/Harvester Wheatsheaf, 1993. See also the interesting discussion of the topic in Michel Serres with Bruno Latour, Conversations on Science, Culture and Time, Ann Arbor: University of Michigan Press, 2004, 143-46.

18 Aris Sarafianos, "The Contractility of Burke's Sublime and Heterodoxies in Medicine and Art", Journal of the History of Ideas 69/1 (2008), 23-48.

19 It is true that, throughout the nineteenth century, Italy frequently became the site of negative projections, or various anxieties and degrees of disillusionment, expressed by British travellers. However, it continued to serve as the sophisticated playground of various cosmopolitan communities of expatriate artists and men of sensibility and education, as well as offering to British liberal elites the modern grounds for strong cultural and political identification (the cult of the Risorgimento). See Maurizio Isabella, "Interlocking Patriotisms: Italy and England in the Long Nineteenth Century", Colin Harrison and Christopher Newall (eds), ${ }^{* * T h e ~ P r e-R a p h a e l i t e s ~ a n d ~ I t a l y * *, ~ O x f o r d: ~ A s h m o l e a n ~ M u s e u m, ~ 2010, ~ 36-40 . ~}$

20 The Last Grand Tour, 32 and 28.

21 Polyglossia, 11.

22 Aris Sarafianos, "The Diaspora of Greek Painting in the Nineteenth Century: Christou's Model and the Case Marie Spartali-Stillman", Historein 6 (2006), 150-169.

23 Caroline Jones, Eyesight Alone: Clement Greenberg's Modernism and the Bureaucratisation of the Senses, Chicago and London: University of Chicago Press, 2005. See also my review "Sensory Politics and Art History: Formalism and Modern Ways of Life", Art History 33/1 (2010), 192-197.

24 Polyglossia, 10-11.

25 Ibid., 16-21, esp. 20.

26 In my translation I render as "reality" Arvanitakis' post-Lacanian term "the Real”. Ibid., 27-28. 